\title{
Dokumentacja konsystorska z XV i początku XVI wieku odkryta w katedrze gnieźnieńskiej ${ }^{1}$
}

\begin{abstract}
Zarys treści: W artykule zaprezentowano informacje o odkrytym w 2015 r. w katedrze gnieźnieńskiej licznym zbiorze dokumentów papierowych z XV i początku XVI w. Jak wskazuje wstępna inwentaryzacja, powstał on w związku z działalnością konsystorza gnieźnieńskiego i składają się na niego m.in. mandaty oficjałów, pisma procesowe pełnomocników stron czy zeznania świadków. Najlepszą analogię do znaleziska stanowią znane z archidiecezji Canterbury i York kolekcje tzw. cause papers. Tekst zamyka edycja sześciu przykładowych dokumentów.

Content outline: The paper presents a large collection of paper documents from the 15 th and early 16th centuries, discovered in Gniezno Cathedral in 2015. Initial analysis shows that it originated in connection with the activities of the Gniezno consistory and contains, among other items, mandates of officials, process writings of plenipotentiaries of sides in court cases or testimonies of witnesses. The best analogy for the finding are the collections of so-called cause papers known from the archdioceses of Canterbury and York. The paper ends with editions of six sample documents.
\end{abstract}

Słowa kluczowe: konsystorz gnieźnieński, sądownictwo duchowne, dyplomatyka kościelna, dokumenty sądowe, cause papers

Keywords: Gniezno consistory, church courts, church diplomatics, legal documents, cause papers

W 1998 r. Archiwum Archidiecezjalne w Gnieźnie przeprowadziło się z pomieszczeń w tamtejszej katedrze Wniebowzięcia NMP do obecnej siedziby przy ul. Kolegiaty 2. Przy przeprowadzce zrezygnowano jednak z przeniesienia do nowego budynku części jednostek archiwalnych znajdujących się w złym stanie zachowania (destrukty, luzy, obiekty zagrzybione) oraz obiektów przedstawiających mniejszą wartość historyczną (dublety prasy, starsza, częściowo zdezaktualizowana literatura naukowa), które pozostawiano w magazynie akt brudnych, mieszczącym się nad północną nawą bazyliki²

1 W poniższym artykule Adam Kozak wydał i omówił dokumenty zamieszczone w aneksie oraz osadził gnieźnieńskie znalezisko w możliwie szerokim kontekście, natomiast Jakub Łukaszewski nakreślił okoliczności odnalezienia dokumentów w gnieźnieńskiej katedrze.

${ }^{2}$ C. P e s t, Przeszłość i współczesność Archiwum Archidiecezjalnego w Gnieźnie, Poznańskie Studia Teologiczne 11, 2001, s. 338-343, gdzie opis pomieszczeń Archiwum Archidiecezjalnego w katedrze oraz kronika przeprowadzki do nowej siedziby. 
W sierpniu i wrześniu 2015 r. Radosław Franczak, Jakub Łukaszewski i Michał Muraszko, uczestnicy projektu „Inwentaryzacja zasobu Biblioteki Katedralnej w Gnieźnie", a także Adam Kozak, dokonali starannej inspekcji wspomnianego pomieszczenia, w trakcie której na betonowej posadzce, wśród przed- i powojennej prasy, ujawniono sześć kartonów wypełnionych po brzegi zabrudzonymi papierami oraz (w większej części) ich fragmentami różnej wielkości ${ }^{4}$. Wstępny ich ogląd, ku wielkiemu zaskoczeniu znalazców, nakazywał datować je na późne średniowiecze. Stan zachowania odnalezionych luzów był zły - były one mocno zabrudzone pyłem ceglanym i wapiennym, niektóre dodatkowo również zagrzybione, niemal wszystkie zaś silnie pomięte, co wydaje się, że jest przyczyną ich stopniowego rozdrabniania. Bezpośrednio po odkryciu A. Kozak i J. Łukaszewski podjęli się oczyszczenia odnalezionych dokumentów, ich przejrzenia i segregacji pod kątem stanu zachowania oraz wstępnej inwentaryzacji, w toku której część dokumentów otrzymała sygnatury archiwalne (utworzono zespół archiwalny ACons. H; proces sygnowania akt nie został dotąd ukończony, stąd niektóre dokumenty będą cytowane w tekście bez sygnatury). $\mathrm{Na}$ jej podstawie można stwierdzić, że na znalezisko składa się około 500 jednostek aktowych zachowanych w całości lub w dużych częściach (pozwalających chociaż na określenie typu dyplomatycznego i orientacyjne wydatowanie) oraz przynajmniej 2000 drobnych fragmentów (w których odczytać można przeważnie po kilka lub kilkanaście słów; przydatność tych skrawków w badaniach historycznych wydaje się wątpliwa). Choć w odnalezionym zbiorze zdecydowanie przeważają jednostki spisane na papierze (por. aneks nr 1, 3-6), to można obok nich wyróżnić też kilka całych sztuk wygotowanych na pergaminie oraz około 70 takowych fragmentów (por. aneks nr 2). Odnalezione akta datować można na wiek XV i początek XVI (za cezurę końcową można przyjąć orientacyjnie rok 1530, przeważają obiekty z II połowy XV wieku). Nie ulega też wątpliwości, że niemal wszystkie z nich powiązane są w jakiś sposób z funkcjonowaniem konsystorza gnieźnieńskiego ${ }^{5}$.

3 Projekt realizowany w latach 2012-2017, finansowany ze środków Narodowego Programu Rozwoju Humanistyki (projekt zespołowy nr 11 H 120179 81; kierownik dr Piotr Pokora, Instytut Historii Uniwersytetu im. Adama Mickiewicza w Poznaniu).

4 Sytuacja ta łudząco przypomina okoliczności odkrycia najstarszej księgi konsystorza lwowskiego z lat 1482-1498, zob. W. R o ln y, Przedmowa, w: Acta officii consistorialis Leopoliensis antiquissima, cz. I, wyd. W. Rolny, Lwów 1927, s. II: „Wydobycie ich [tj. akt konsystorskich - AK, JŁ] zawdzięczamy - jak to się nieraz zdarza - przypadkowi. Przypadkiem bowiem odnaleźli przed laty z górą 20 prof. Abraham i ś.p. W. Kętrzyński w pokoju nad zakrystią, czyli tzw. skarbcu lwowskiej bazyliki łac[ińskiej] wśród zakurzonych rupieci księgę papierową z XV w.”.

5 Zob. wstępny komunikat o odkryciu: A. K o z a k, J. Ł u k a s z e w s k i, Późnośredniowieczne dokumenty papierowe odnalezione w katedrze gnieźnieńskiej, Studia Gnesnensia 29, 2015, s. 359-361, oraz nota prasowa S. Zdziebłowskiego z wypowiedziami znalazców w serwisie Nauka w Polsce PAP: <http://naukawpolsce.pap.pl/aktualnosci/news,407907,w-gnieznie-odkryto-olbrzymi-zbior-sredniowiecznych-dokumentow.html>. W listopadzie 2017 r. zakończono sfinansowane przez Ministerstwo Kultury i Dziedzictwa Narodowego oraz Archidiecezję Gnieźnieńską prace konserwatorskie (wykonawca: Marzena Szczerkowska, Pracownia Konserwacji Zabytków Verso w Gnieźnie) przy pierwszych 345 odnalezionych dokumentach, <http://www.archidiecezja.pl/aktualnosci/archiwum/2017/listopad/archiwalia uratowane.html>. 
Niniejszy tekst stawia sobie trzy zasadnicze cele: wskazanie, skąd wzięły się niezinwentaryzowane akta $\mathrm{w}$ magazynie akt brudnych z gnieźnieńskiej katedry, przedstawienie najczęściej spotykanych typów dokumentów w znalezisku (na podstawie analizy wybranych jednostek, których edycja umieszczona zostanie w aneksie), wreszcie odnalezienia analogii do gnieźnieńskiego zespołu dokumentów.

$\mathrm{W}$ celu ustalenia pochodzenia dokumentów podjęto m.in. kwerendy w zespole Archiwum-Biblioteka, w którym znajdowały się roczne sprawozdania z działalności archiwisty i bibliotekarza kapituły metropolitarnej gnieźnieńskiej sprzed 1960 r., kiedy to erygowano Archiwum Archidiecezjalne ${ }^{6}$. W dalszej kolejności przejrzane zostały akta dotyczące powojennej odbudowy katedry, których zawartość przyniosła przełom w prowadzonych poszukiwaniach. W sprawozdaniu z 18 IX $1961 \mathrm{r}$. odpowiedzialny za restaurację katedry ks. Jan Michalski informował prymasa Stefana Wyszyńskiego: „Przy oczyszczaniu z gruzu chóru, zwłaszcza grubo nałożonego w pachach stropu b[yłego] kapitularza, znaleźliśmy wiele manuskryptów, dokumentów itp. dot. głównie Oficjalatu Gnieźnieńskiego. Niektóre zostały zachowane w całości, inne zupełnie zniszczone. Pochodzenie ich datuje się na pierwszą połowę 15 wieku. Dotyczą one również stosunków z innymi diecezjami: np. odpis erekcji parafii Skoki /diec. pozn./, święceń w diec. płockiej. W związku z cennymi odkryciami trzeba będzie usunąć cały gruz z chóru i zbadać, czy są inne jeszcze znaleziska" . Po odkryciu dokumentów kapituła gnieźnieńska zleciła ich zabezpieczenie archiwariuszowi, ks. kanonikowi Antoniemu Słomkowskiemu. W grudniu 1961 r. zbiór zdeponowano w Archiwum Archidiecezjalnym ${ }^{8}$. Luzy wstępnie oczyszczono i przełożono do sześciu pudeł, w których niewątpliwie przed II wojną światową przechowywano dyplomy pergaminowe. Około 40 dokumentów (w całości i fragmentach) zostało prowizorycznie zabezpieczonych, rozprostowanych i przełożonych czystym papierem. Ks. Władysław Zientarski (dyrektor Archiwum Archidiecezjalnego w latach 1961-1991), podjął nawet próbę inwentaryzacji znaleziska, o czym świadczy odnaleziona pomiędzy dokumentami

${ }^{6}$ W sprawozdaniu za 1932 r. poinformowano m.in. o znalezisku z 25 maja, kiedy to z podłogi wieży północnej katedry wydobyto 28 sztuk archiwaliów z XV i XVI w., m.in. dokumenty arcybiskupa gnieźnieńskiego Andrzeja Róży Boryszewskiego (1503-1510) oraz list do kanonika gnieźnieńskiego Wojciecha Załuskiego z 1520 r. - Archiwum Archidiecezjalne w Gnieźnie (dalej cyt.: AAG), Archiwum-Biblioteka, Korespondencja 1933-1934, k. 128-129. Za nieocenioną pomoc w kwerendzie poświęconej ustaleniu okoliczności odnalezienia zbioru dokumentów serdecznie dziękujemy Pani Justynie Mizerce, kustosz Archiwum Archidiecezjalnego w Gnieźnie.

7 AAG, Akta Kurii Metropolitalnej I, sygn. 1189 (Odbudowa Katedry 1961), bez paginacji/ foliacji, maszynopis z datą 18 IX $1961 \mathrm{r}$.

8 AAG, ACap. B 48, Protokolon sesji 1957-1980, k. 104v-105 (posiedzenie kapituły 13 X 1961 r.): „Podczas remontu chóru muzycznego znaleziono strzępy akt sądowych i innych dokumentów z w. XV. Kapituła zleciła archiwariuszowi, księdzu kanonikowi Antoniemu Słomkowskiemu zapoznanie się z znaleziskiem i zabezpieczenie prawa własności Kapituły"; k. 108v (posiedzenie kapituły z 11 XII 1961 r.): „Ks. Kanonik A. Słomkowski, archiwariusz kapitulny poinformował Kapitułę, że wykonał zlecone sobie zadanie i stwierdził, iż dokumenty archiwalne znalezione w chórze muzycznym w Bazylice są pieczołowicie konserwowane [sic! - AK, JŁ] w Archiwum Archidiecezjalnym i że Odbudowa Katedry usuwając gruzy dokłada starań, by nie uszkodzić ewent. nowego znaleziska dokumentów, sam również zwróci na okoliczność tę uwagę". 
w 2015 r. jedna fiszka, z niepełnym regestem jednego z listów9. Dalszych prac nad znaleziskiem jednak nie prowadzono. Warto w tym miejscu zauważyć, iż w dokumentacji własnej gnieźnieńskiego archiwum (sprawozdania i korespondencja z lat 1960-1975) nie ma żadnych wzmianek o znalezieniu tych dokumentów czy o podjętej próbie ich inwentaryzacji ${ }^{10}$. Znalezisko nie trafiło również do naukowego obiegu. Nie wspominali o nim w swych pracach pracownicy Archiwum: Jadwiga Rył ani księża W. Zientarski, Marian Aleksandrowicz i Czesław Pest ${ }^{11}$. Tożsamość znalezisk z lat 1961 i 2015 nie ulega jednak wątpliwości - świadczy o niej identyczny opis proweniencji i stanu fizycznego dokumentów czy liczba odkrytych dokumentów. Dodatkowo w odnalezionym w 2015 r. zbiorze dokumentów znajdują się rzeczywiście kopia dokumentu erekcyjnego parafii Skoki (aktu dokonano w 1373 r.) (2) $^{12}$ oraz fragment składki z wykazem wyświęconych ${ }^{13}$, wyraźnie wspomnianych w cytowanym liście ks. J. Michalskiego.

Odnalezione dokumenty, jak nadmieniono wyżej, powiązane są niewątpliwie z funkcjonowaniem późnośredniowiecznego konsystorza arcybiskupiego w Gnieźnie $^{14}$. Podzielić je można wstępnie na trzy grupy (wyczerpujące około $75 \%$ zbioru):

${ }^{9}$ Chodzi o list mieszczki poznańskiej Balcerowej z 1477 r. do oficjała gnieźnieńskiego, obecna sygn: AAG, ACons. H 149. Na drukowanej karcie katalogowej (z numerami cenzorskimi w stopce) zapisano ręcznie względnie poprawny regest (pisownia oryginalna): „Prośba wdowy Anny Balcerowej do Officiała Gnieźnieńskiego o szybkie i skuteczne wstawiennictwo w sprawie odzyskania 20 marek od Sczekoczkiego kanonika. Poznan 1447 [sic!], feria secunda post nativitatem $\mathrm{X}[=\mathrm{Christi}-\mathrm{AK}, \mathrm{J}]]^{\prime}$.

10 AAG, Archiwum-Biblioteka, akta bez sygnatur: Działalność Archiwum Archidiecezjalnego w Gnieźnie 1927, 1945- (tam: Sprawozdania z rocznej działalności Archiwum Archidiecezjalnego w Gnieźnie z lat 1960-1975); Dziennik zajęć 1966.1.IX - 1969.31.XII; Księga zajęć 1970.2.I - 1973.1.IX; Dziennik korespondencji Biblioteki Kapitulnej w Gnieźnie, Gniezno od 15.V.1957 do 16.VI.1969; Korespondencja dotycząca rękopisów i druków bibliotecznych (2 segregatory); Korespondencja 1957-1959; AAG, Akta Kurii Metropolitalnej I, sygn. 1823 (1956-1968. Archiwum Archidiecezjalne).

11 J. Rył, Biblioteka Katedralna w Gnieźnie, Lublin 1978; t a ż, Biblioteka Katedralna w Gnieźnie w latach 1650-1975, Lublin 1985; M. A l e k s a n d r o w i c z, J. R y ł, W. Z i e n t a r s k i, Archiwum Archidiecezjalne w Gnieźnie, w: Dzieje Poznania i Województwa Poznańskiego (w granicach z 1974 r.). Informator o materiałach archiwalnych, t. II, Warszawa 1982; M. A l e k s a n drow i c z, Źródła rękopiśmienne do dziejów archidiecezji gnieźnieńskiej w Archiwum Archidiecezjalnym w Gnieźnie, w: 1000 lat Archidiecezji Gnieźnieńskiej, Gniezno 2000, s. 420-426; C. P e s t, Przeszłość, s. 337-346.

12 AAG, ACons. H 168. Wydaje się, że kopia została sporządzona w początkach XVI w. na potrzeby jakiegoś sporu sądowego toczącego się w konsystorzu gnieźnieńskim, o czym świadczy adnotacja: Auscultata per me Benedictum Isdbiensky notarium publicum sacris apostolica et imperiali auctoritatibus et concordat in toto cum suo originali. Dokument wydano drukiem na podstawie późniejszych kopii z lat 1576 i 1714: Kodeks dyplomatyczny Wielkopolski, t. VI, wyd. A. Gąsiorowski, H. Kowalewicz, Warszawa-Poznań 1982, nr 240.

${ }_{13}$ AAG, bez sygnatury. Odnaleziony fragment składki w formacie dutki składa się z 4 kart zachowanych jedynie w górnej części, datować go można na podstawie kryteriów pośrednich (wymienieni w tekście urzędnicy udzielający prowizji na beneficja) na początek lat szcześćdziesiątych XV w. Wbrew ocenie ks. J. Michalskiego wiązać należy go raczej z diecezją gnieźnieńską. Wykaz będzie przedmiotem odrębnego przyczynku połączonego z edycją.

14 Jego kompetencje i funkcjonowanie omawiają szczegółowo: A. G ą s i o row ski, I. S ki e rska, Średniowieczni oficjałowie gnieźnieńscy, Roczniki Historyczne 61, 1995, 
1) dokumenty wystawiane przez oficjałów gnieźnieńskich lub osoby działające na ich zlecenie (przeważnie mandaty adresowane do kleru archidiecezji); 2) dokumenty i listy kierowane do konsystorza gnieźnieńskiego; 3) pisma procesowe stron spierających się przed konsystorzem gnieźnieńskim (libelli, positiones, interrogatoria i inne). Ze względu na obecny etap badań zostaną one omówione jedynie na wybranych przykładach, czysto orientacyjnie można jednak wskazać (na podstawie analizy ok. 400 najlepiej zachowanych jednostek), że do poszczególnych grup przynależy odpowiednio 140, 40 i 120 sztuk.

Do pierwszej grupy zaliczyć można niewątpliwie dokument Mikołaja z Czechla z 30 IX 1454 r. (zob. aneks nr 3) ${ }^{15}$, który jako oficjał gnieźnieński polecił wikariuszowi kościoła parafialnego w Sobótce, aby wezwał on tamtejszego plebana Piotra do stawienia się przed sądem konsystorskim w Gnieźnie na rozprawie z kanonikiem gnieźnieńskim Piotrem Bardzkim ${ }^{16}$. Ta miała się odbyć dziewiątego dnia od daty wykonania mandatu, o ile przypadać będzie wtedy dzień sądowy (w uproszczeniu: poniedziałek, środa lub piątek z pominięciem ważniejszych świąt), lub w pierwszy dzień sądowy po tej dacie ${ }^{17}$. Zlecenie wikariusza zostało wykonane 11 października, co wynika z noty na odwrociu pisma, jaką nakreślił własnoręcznie Piotr, ówczesny

s. 36-86, oraz I. S k i e r s k a, Konsystorz gnieźnieński w XV wieku, w: 1000 lat Archidiecezji Gnieźnieńskiej, Gniezno 2000, s. 193-215; zob. też prace ogólniejsze: A. Ve tu la n i, Prawne stanowisko oficjałów biskupich w Polsce w XV stuleciu, w: Studia historyczne ku czci Stanisława Kutrzeby, t. I, Kraków 1938, s. 471-491; I. S u b e r a, Powstanie i rozwój właściwości sądów kościelnych w Polsce, Prawo Kanoniczne 11, 1968, nr 3-4, s. 57-80; Ch. D o n a h u e Jr., The Ecclesiastical Courts: Introduction, w: The History of Courts and Procedure in Medieval Canon Law, Washington 2016, s. 247-299.

15 Lokalizację wymienionych w dokumentach miejscowości oraz informacje o występujących osobach podajemy wyłącznie w przypisach rzeczowych w edycji.

16 Mandaty oficjalskie zlecające niższemu klerowi wzywanie podsądnych lub świadków na rozprawy są jednym z najczęściej występujących w omawianym zbiorze. Por. ACons. H 97 (23 IX 1467: Piotr z Pniew oficjał gnieźnieński poleca hebdomadariuszowi chóru katedry gnieźnieńskiej wezwać Andrzeja młynarza z Raciąża, aby stawił się w oznaczonym terminie przed oficjałem w Gnieźnie na rozprawie z Maciejem opatem w Trzemesznie; wykonawca mandatu Wojciech z Łabiszyna w nocie o wykonaniu zaświadczył, że wezwał Andrzeja podług zwyczaju, przywieszając pozew do drzwi kościoła); ACons. H 110 (5 V 1501: Klemens z Piotrkowa oficjał gnieźnieński poleca hebdomadariuszowi chóru katedry gnieźnieńskiej wezwać Erazma Karskiego, osobiście lub przez przybicie pozwu do drzwi katedry, aby stawił się w oznaczonym terminie przed oficjałem w Gnieźnie na rozprawie z Jakubem z Wyszogrodu; wykonawca mandatu Janusz wikariusz wieczysty w katedrze wezwał Erazma, korzystając z drugiej opcji); wariacją omawianego typu dokumentu jest mandat o sygnaturze ACons. H 91 (1463, w Sarnowie): Łaskarz pleban w Broniszewie, sędzia komisarz oficjała gnieźnieńskiego Mikołaja z Czechla, poleca plebanom bądź wikariuszom kościołów parafialnych w Wąsoszy i Ślesinie wezwać wskazanych imiennie świadków na planowane przesłuchanie przed komisarzem w Ślesinie; niewątpliwie po zakończeniu postępowania komisarskiego Łaskarz odesłał całą wytworzoną dokumentację do konsystorza gnieźnieńskiego (stąd można wahać się, czy niniejszy akt, niemal identyczny formularzowo z poprzednimi, zaliczyć należy do pierwszej czy drugiej z zaproponowanych grup; w przedstawionym wyżej podliczeniu na podstawie 400 najlepiej zachowanych dokumentów zaliczyśmy je do pierwszej grupy).

17 Zagadnienie dnia sądowego oraz terminów, w których sesje nie mogły się odbywać, odnośnie do polskich sądów duchownych wyczerpująco omówiła I. S k i e r s k a, Sabbatha sanctifices. Dzień święty w średniowiecznej Polsce, Warszawa 2008, s. 372-388. 
wikariusz w Sobótce. Jako że dziewiąty dzień od wykonania mandatu przypadał w niedzielę 20 października, a sesja poniedziałkowa nie mogła się odbyć ze względu na przypadające w ten dzień święto Jedenastu Tysięcy Dziewic ${ }^{18}$, wezwany pleban winien się zatem stawić w Gnieźnie w domu zamieszkania oficjała, gdzie zwyczajowo odbywały się posiedzenia sądu ${ }^{19}$, dopiero w środę 23 października. Z kolejnej noty umieszczonej na stronie dorsalnej dokumentu wynika jednak niezbicie, że pleban z Sobótki tego nie uczynił, wskutek czego oficjał, ustaliwszy, że Piotr został prawidłowo wezwany (dowód tego stanowiła adnotacja wikariusza na omawianym mandacie, który tymczasem odesłano do Gniezna), uznał go za winnego niestawiennictwa na rozprawę ${ }^{20}$.

Kolejnym aktem, który można zaliczyć do pierwszej grupy, jest dokument (ściślej: littera remissorialis) wystawiony 17 II 1490 r. przez Jana z Goślubia, gnieźnieńskiego oficjała i wikariusza in spiritualibus (aneks nr 5). Pismo było skierowane do Tomasza oficjała foralnego w Kamieniu Krajeńskim oraz Grzegorza plebana w pobliskiej Dużej Cerkwicy ${ }^{21}$. Jan poinformował $\mathrm{w}$ nim adresatów, że przed jego sądem toczy się proces Stanisława plebana w Tucholi przeciwko tamtejszym władzom miejskim, w trakcie którego Grzegorz z Kamieńca, pełnomocnik plebana, zwrócił się do sądu z prośbą, aby ze względu na dużą odległość (około $120 \mathrm{~km}$ w linii prostej), trudy podróży oraz jej koszty, którym świadkowie nie byliby w stanie sprostać, zechciał zlecić przesłuchania komuś innemu. $Z$ tego też względu Jan polecił Tomaszowi i Grzegorzowi zająć się niniejszą sprawą 22 . Treść mandatu uzupełniona została dokładnym opisem procedury, jaką przy przesłuchaniach winni stosować sędziowie komisaryczni: mieli wezwać świadków wskazanych przez plebana lub jego pełnomocnika, zaprzysiąc ich w obecności drugiej strony, pytania miały być zaś stawiane na podstawie pisma

18 AAG, ACons. A 34, k. 123v: Die Lune XXI mensis Octobris fuit festum Undecim Miliarum Virginum, in quo audiencia non fuit tenta.

19 Por. A. K o z a k, Miejsca działalności konsystorza generalnego w Poznaniu i jego pisarzy w pierwszej ćwierci XV w., w: Loca scribendi. Miejsca i środowiska tworzące kulturę pisma w dawnej Rzeczypospolitej XV-XVIII stulecia, Warszawa 2017, s. 126-151, gdzie na przykładzie konsystorza poznańskiego przedstawiono ucieranie się praktyki odbywania sądów w miejscu zamieszkania każdorazowego oficjała.

20 Informacji o rozprawie nie podaje księga wpisów konsystorza gnieźnieńskiego z 1454 r. (AAG, ACons. A 34, k. 124-125, na których odnotowano sesję z 23 października). Ogłoszenie kontumacji jednej ze stron sporu w procedurze rzymsko-kanonicznej, najogólniej rzecz ujmując, znacząco pogarszało jej sytuację procesową (inne były jej skutki względem powoda, inne zaś wobec pozwanego, zależały one też od fazy sporu czy przedmiotu roszczenia), szczegółowo zob. H. J. B u d i s c h i n, Der gelehrte Zivilprozeß in der Praxis geistlicher Gerichte des 13. und 14. Jahrhunderts im deutschen Raum, Bonn 1974, s. 41-72; W. L i t e w s k i, Der römisch-kanonische Zivilprozeß nach den älteren ordines iudiciarii, Kraków 1999, s. 275-298.

${ }^{21}$ Por. I. S k i e r s k a, Sądownictwo oficjałów okręgowych (foralnych) w późnośredniowiecznej Polsce, w: Sacri canones servandi sunt. Ius canonicum et status ecclesiae saeculis XIII-XV, Praha 2008, s. 352-360.

22 Por. bardziej lakoniczną zapiskę z księgi wpisów (AAG, ACons. A 58, k. 219, rozprawa z 17 II 1490 r.): In causa Stanislai plebani in Tuchola contra proconsulem et consules de ibidem --dominus ad peticionem Gregorii procuratoris plebani decrevit litteras remissionis pro examinandis testibus in personas honorabilium dominorum Thome officialis Camenensis et Gregorii plebani in Czirquicza coniunctim - - et ibidem Nicolaus de Wolborz citatus est ad dandum interrogatoria, que dabit hodie. 
dostarczonego jako załącznik do dokumentu (interrogatoria), a protokół miał być zaś sporządzony „w jednym tomie” (in uno volumine) przez notariusza publicznego. Tak przygotowana korespondencja miała być następnie opieczętowana przez komisarzy i zaniesiona do Gniezna przez zaprzysiężonego posłańca. Na odwrociu omawianego dokumentu znalazła się odpowiedź Tomasza oficjała kamieńskiego, w której informował on mocodawcę o podjętych w sprawie czynnościach - co ciekawe, Tomasz zaznacza w niej, że z braku notariusza pisze ,własną ręką”. Finał postępowania nie jest niestety znany ${ }^{23}$. Udzielenie tak szczegółowych instrukcji komisarzom jest dość zaskakujące, ponieważ liczne przekazy źródłowe wskazują, że w rozległej diecezji gnieźnieńskiej korzystano z tej procedury dość często ${ }^{24}$, wydawać by się mogło zatem, że odbiorcy mandatu doskonale wiedzieli, co czynić w takiej sytuacji.

Podsumowując omawianie pierwszej grupy, można wskazać jej cechy wspólne: 1) wystawienie dokumentów przez oficjałów lub osoby działające na ich zlecenie; 2) sformułowano w nich polecenia do niższego kleru, często działającego poza Gnieznem; 3) zobowiązanie adresatów pisma do rozliczenia się z jego wykonania oraz odesłania go do konsystorza gnieźnieńskiego; 4) wykorzystanie dokumentu $\mathrm{w}$ procesie toczącym się $\mathrm{w}$ oficjalacie.

W odnalezionym zbiorze wyróżnić można również różnorodny zespół aktów kierowanych do konsystorza gnieźnieńskiego. Pierwszym przykładem może być pergaminowy dokument wystawiony 12 VIII 1451 r. przez braci Andrzeja i Jana, dziedziców w Żernikach, w którym prezentowali oni Stanisława syna Franciszka z Juncewa na plebana w Łopiennie (aneks nr 2). Fakt skierowania prezenty do Władysława Oporowskiego bądź jego wikariusza generalnego pokazuje duży stopień sformalizowania czynności prawnych w późnośredniowiecznym Kościele polskim (postępującego tu oczywiście zgodnie z normami prawa powszechnego). Instytucja Stanisława na plebana w Łopiennie nie przebiegała jednak bezproblemowo: co prawda według zapisów z księgi urzędowej Sędka z Czechla, ówczesnego gnieźnieńskiego wikariusza in spiritualibus, już w dniu otrzymania prezenty otrzymał on niniejsze beneficjum w tymczasowy zarząd (in commendam) ${ }^{25}$, jednakże dwa tygodnie

${ }^{23}$ W księdze wpisów konsystorza gnieźnieńskiego odnaleźć można jeszcze kilka wpisów tyczących się sprawy: AAG, ACons. A 58, k. 217, 218, 223 (26 II: in causa domini Stanislai plebani in Tuchola - - honorabilis Simon prepositus hospitalis de ibidem iuravit de fideliter portando rotulum pro parte plebani; por. aneks $\mathrm{nr} 5$, nota sędziego komisarza), 231v, 235, brak jednak bliższych informacji o przedmiocie sprawy (w księdze brak wpisów z okresu, kiedy rozgrywała się pierwsza faza procesu). Milczenie źródeł w kwestii rozstrzygnięcia sporu może sugerować zawarcie ugody (por. zapisy księgi wyroków z 1490 r.: AAG, ACons. C 3, k. 48v-59v, gdzie również brak wzmianki o tucholskim sporze).

${ }^{24}$ Por. księga ACons. B 3 w AAG (spisana w latach 1482-1492), która w około połowie składa się z protokołów zeznań świadków przesłuchiwanych na zlecenie gnieźnieńskich władz kościelnych w odległych częściach diecezji (np. w Łęgonicach w województwie sandomierskim) przez wyznaczonych komisarzy. Por. też dokumenty wydane w aneksie pod nr 1 i 6 .

${ }_{25}$ AAG, ACons. A 30, k. 47: Eodem die [12 VII 1451] veniens personaliter nobilis Johannes Zyrniczsky heres in Lopyenno presentavit viva voce honorabilem dominum Stanislaum plebanum in Zyrniky ad ipsam ecclesiam in Lopyenno, vacantem per olim dominum Johannem Rode. Et dominus decrevit cridam, comendavit ecclesiam prefatam in Lopyenno eidem Stanislao. Zwrócić należy uwagę na pewne różnice w przekazach, jakimi dysponujemy: według księgi aktu prezenty dokonano ustnie, a dokument nie jest w ogóle wspomniany, w pergaminie 
później wywiązał się pomiędzy kolatorami kościoła parafialnego spór (prawo prezenty rościł sobie także Benedykt [z Łopienna?] ${ }^{26}$, kontynuowany następnie przed sądem oficjała $^{27}$. Właśnie z tym procesem wiązać należy notę o oblacie z 24 III 1452 r., tego dnia bowiem pełnomocnik Jana i Andrzeja przedstawił w celach dowodowych oficjałowi Mikołajowi z Czechla dokument prezenty ${ }^{28}$.

Jak była mowa wyżej, w związku z rozległością diecezji gnieźnieńskiej oficjałowie gnieźnieńscy często zlecali przesłuchiwanie występujących w procesach świadków sędziom komisarzom, co wydatnie ułatwiało postępowanie i obniżało jego koszty ${ }^{29}$. Niezbędne to było również w przypadku spraw apelacyjnych, spływających z obszaru całej metropolii ${ }^{30}$. Nie może $w$ tej sytuacji dziwić odnalezienie $w$ omawianym zbiorze dokumentów z gatunku depositiones. Za przykład niech posłuży zwięzły protokół zawierający zeznania czterech świadków, od których próbowano dowiedzieć się, czy Jan Szadkowski spłacił dług zmarłemu Piotrowi Pacanowskiemu (aneks nr 6). Wszyscy świadkowie (trzech zeznających znało sprawę z autopsji, ostatni zaś ex fama) potwierdzili uiszczenie spornych 20 grzywien. Na odwrociu dokumentu nie ma niestety żadnych not, co uniemożliwia jego dokładną datację oraz odnalezienie procesu w księgach wpisów ${ }^{31}$.

wskazano ponadto, że właściwej władzy dostarczyć go miał sam Stanisław. Być może świadczy to o próbie dwutorowego załatwienia sprawy: Jan Żernicki udał się do Gniezna, gdzie stale rezydował wikariusz in spiritualibus, natomiast Stanisław wraz z dokumentem udał się na poszukiwanie podróżującego arcybiskupa Oporowskiego; miejsce jego pobytu między $17 \mathrm{X}$ 1450, kiedy to przebywał w Łowiczu, a 27 IV 1451 r., kiedy to jest poświadczony w Gnieźnie, nie jest znane - Z. Wilk-Woś, Późnośredniowieczna kancelaria arcybiskupów gnieźnieńskich (1437-1493), Łódź 2013, s. 307.

26 AAG, ACons. A 30, k. 47v (25 VIII 1451): Dominus vicarius in spiritualibus prorogavit terminum collatoribus ecclesie in Lopyenno per XIIII dies ad concordandum de comendario nobili Thoma patrono et herede in Lopyenno comparente, presentibus dominis et si non concordaverint in termino predicto de comendario, extunc dominus ex officio providebit de comendario.

27 AAG, ACons. A 32 (1452), k. 14, 23, 24v, 28, 32v, 38v, 62v, 65, 73, 79v. Rozstrzygnięcie nie zostało odnotowane w księdze wyroków: AAG, ACons. C 1, k. 166-177v (rok 1452).

${ }_{28}$ AAG, ACons. A 32, k. 32v (24 III 1452): - - et ibidem Petrus Apostolus nomine partis sue - - produxit presentacionem sub titulis et sigillis Jo(hannis) et Andree de Zirniky et cridam cum comenda pro verificacione intencionis sue --. Być może przechowanie dokumentu w niniejszym zbiorze wiąże się nie z faktem skierowania go do konsystorza gnieźnieńskiego, ale wynika $\mathrm{z}$ wykorzystaniem go jako dowodu w procesie.

${ }_{29}$ Diecezja gnieźnieńska podzielona była w XV w. na 8 oficjalatów foralnych, jednak ich kompetencje były ograniczone (zakaz sądzenia wybranych kategorii spraw czy rozstrzygania procesów, w których wartość przedmiotu sporu przekraczała wskazaną w nominacji oficjała kwotę, najczęściej 12 grzywien), zob. A. G ą s i o r o w s k i, I. S k i e r s k a, Oficjalaty okręgowe w późnośredniowiecznej archidiecezji gnieźnieńskiej, Czasopismo Prawno-Historyczne 47, 1995, z. 1-2, s. 108-111.

30 I. S k i e r s k a, Konsystorz gnieźnieński, s. 197.

31 Znacznie bardziej rozbudowane są zeznania Marcina i Jana sług plebana w Powidzu, którzy ze szczegółami opowiadali o tym, jak w czasie zwożenia siana z łąk w lasach pod Powidzem zostali napadnięci przez Marcina Twierdzińskiego i jego kompanów; dokument ten (AAG, bez sygnatury; poważnie uszkodzony) również pozbawiony jest jakichkolwiek not i datacji. Do prezentowanej grupy zaliczyć też można mandat arcybiskupa gnieźnieńskiego Jakuba z Sienna wystawiony w Opatówku 21 XI 1476 r. (ACons. H 27) skierowany do oficjała 
Druga grupa omawianych dokumentów jest niewątpliwie bardziej różnorodna niż poprzednia, co być może winno stanowić zachętę do uściślania $\mathrm{z}$ biegiem prac klasyfikacji. Cechami wspólnymi są tu urzędowy charakter korespondencji oraz skierowanie jej do oficjałów lub wikariuszy in spiritualibus.

Ostatnią z wyróżnionych grup stanowią różnego typu pisma procesowe stron spierających się przed konsystorzem gnieźnieńskim (libelli, positiones, articuli, interrogatoria, taxationes i inne) $)^{32}$. Zachowały się one w gnieźnieńskim zbiorze stosunkowo licznie, większość z nich jednak w złym stanie. Szczęśliwie do czasów współczesnych niemal w całości dotrwało protestatio złożone w 1445 r. przed sądem oficjała Mikołaja z Kalisza przez pełnomocnika reprezentującego kolatorów kościoła parafialnego w Zbylitowskiej Górze, Dobiesława z Chyszowa i Piotra z Dąbrówki prepozyta tarnowskiego oraz prezentowanego przez nich na plebana Macieja syna Benedykta ze Strzeszewa (aneks nr 1; sprawa rozpatrywana była w Gnieźnie w II instancji). Toczyli oni spór o prawo patronatu wspomnianego kościoła z Mikołajem Brzechwą ze Zbylitowskiej Góry, Janem Rokoszem z Koszyc oraz prezentowanym przez nich Mikołajem z Trzemeśni. W zawiłym piśmie niewymieniony z imienia pełnomocnik (skądinąd wiadomo, że był to Peregryn syn Klemensa z Pępic - jeden z aktywniejszych gnieźnieńskich prawników praktyków ${ }^{33}$ ) wnosił o wydanie w sprawie wyroku przedstanowczego w kwestii unieważnienia zlecenia przesłuchania świadków przez komisarza Dziersława Borzymowskiego archidiakona krakowskiego oraz niedopuszczenie do sprawy protokołów ich zeznań. Akt w momencie odnalezienia zwinięty był „w harmonijkę”, tak aby na wierzchnich stronach, bez konieczności rozwijania pisma, były widoczne jego regest i informacja o dacie przedłożenia go sądowi (oblacie ${ }^{34}$ ), która w tym przypadku wskazywała 10 X $1445 \mathrm{r}^{35}$ Jest to jednocześnie terminus ante quem powstania tego niedatowanego dokumentu.

gnieźnieńskiego Piotra z Pniew, w którym prymas informował go, że po wstępnym rozpoznaniu sprawy Jana ze Szczytna i przedmieszczan warszawskich, zdecydował się powierzyć mu dalsze prowadzenie sporu. Do grupy tej zaliczyć można też wspomniany wyżej list wdowy Anny Balcerowej.

32 Warto zauważyć, że średniowieczne podręczniki procedury kanonicznej wyróżniają kilkanaście rodzajów pism procesowych stron (W. Li te w s ki, Der römisch-kanonische Zivilprozeß, według indeksu).

33 A. G ą s i o r o w s k i, Notariusze publiczni w Wielkopolsce schyłku wieków średnich, Poznań 1993, nr 529; zastępcą procesowym drugiej strony był Wojciech zwany Romanus, syn Stanisława z Jezierc (o którym tamże, nr 35).

${ }^{34}$ Mikołaj Puchník w traktacie Processus iudiciarius secundum stilum Pragensem (powstały w 1. 1386-1389 podręcznik procedury kanonicznej), omawiając przedłożenie libelli sądowi, dawał następującą instrukcję notariuszowi konsystorskiemu: Notarius scribit in carta libelli in hunc modum: Die secunda mensis talis oblatus est libellus (D. B u d s k ý, Mikuláš Puchník. Život a právnické dílo, Praha 2016, s. 121).

35 AAG, ACons. A 26, k. 139v (1 X 1445): In causa iuris patronatus ecclesie in Gora Crac(oviensis) dyocesis Ro(manus) procurator nobilis Jo(hannis) Rokosz et Nicolai Brzechwa ac Nicolai ipsorum presentati < produxit rotulum attestacionum pro parte sua allatum petens apperiri eundem et ad causam admitti et allegavit> allegavit [!] impedimenta, propter que remissio infra tantum tempore non fuit expedita - - Ex adverso magister Peregrinus procurator partis sue protestatus est per - - actum infrascriptum non consentit nec consentire intendit in aparicionem et publicacionem rotuli seu attestacionum ibique produxit responsiones 
Kolejnym przykładem pisma procesowego jest dokument z 1462 r., w którym pełnomocnik Andrzeja wicekustosza włocławskiego zwraca się do oficjała gnieźnieńskiego Mikołaja z Czechla o zasądzenie od Dadźboga ze Szpiegowa (dotychczasowa literatura posługuje się nazwą historyczną: Śpiegowo) stolnika dobrzyńskiego (niniejszy dokument jest najwcześniejszym poświadczeniem piastowania przez niego tegoż, urzędu) 2 kóp groszy z tytułu zaległej dziesięciny snopowej z ról folwarcznych w Szpiegowie stanowiących uposażenie kustodii włocławskiej (aneks nr 4). W tytuliku akt określony jest jako libellus convencionalis summarius, co oznacza, że jest to pismo otwierające spór (w tym przypadku proces w II instancji), w którym powód winien przedstawić i uzasadnić swoje roszczenie. Pismo zostało odnalezione $\mathrm{w}$ formie rozwiniętej, ale i w tym przypadku widać charakterystyczny nagłówek i zagięcia, świadczące o uprzednim zwinięciu w ,harmonijkę” bądź ,trąbkę” (in rotulo alias $v$ trambke, jak określa tę formę jeden z niezinwentaryzowanych dokumentów odnalezionych w zbiorze). Nota o oblacie wskazuje, że pismo zostało przedstawione w konsystorzu gnieźnieńskim 23 czerwca, co zgodne jest z zapisami księgi sądowej Mikołaja z Czechla ${ }^{36}$. Warto dodatkowo zauważyć, że tekst dokumentu jest silnie sformalizowany, liczne zwroty prawnicze dominują w nim nad opisem spornej sytuacji.

Podsumowując, można wymienić kilka cech charakterystycznych grupy: 1) przygotowanie dokumentów przez zawodowych pełnomocników w imieniu mocodawcy; 2) specyficzna forma zewnętrzna: pisma przechowywane były niewątpliwie w formie harmonijek, złożonych tak, by można było szybko ustalić, jakiej sprawy dane pismo dotyczy; 3) silne sformalizowanie treści, szerokie wykorzystanie prawniczej terminologii, zgodnie z wymogami procesu kanonicznego.

Z podanej wyżej klasyfikacji w pewien sposób wyłamuje się niewielka część odnalezionego zbioru, na którą składają się m.in. fragmenty ksiąg wpisów oficjałów gnieźnieńskich (w tym 2 karty z najstarszymi znanymi zapisami tego sądu z 1399 r.),

et excepciones < infrascripti, quare rotulus non debet recipi et apperiri $>$ contra remissionem et rotulum attestacionum - -. Por. wyrok końcowy: AAG, ACons. C 1, k. 118v-119 (1 VII 1446), w którym Mikołaj z Kalisza utrzymał wyrok pierwszej instancji na rzecz Piotra prepozyta tarnowskiego, Dobiesława z Chyszowa i Macieja ze Strzeszewa wydany przez oficjała krakowskiego Rafała ze Skawiny (pełnił funkcję w 1. 1440-1449: E. K n a p e k, Akta oficjalatu i wikariatu krakowskiego do połowy XVI wieku, Kraków 2010, s. 197).

${ }^{36}$ AAG, ACons. A 42, k. 89v: In causa appellacionis domini Andree vicecustodis ecclesie Wlad(islaviensis) contra nobilem Daczbogium heredem de Spiegowa P(etrus) Apostolus procurator vicecustodis oblata citacione debite executa per edictum accusavit contumaciam eiusdem nobilis et suorum procuratorum non comparencium - - produxit libellum convencionalem, petens admitti et partem adversam ad respondendum compelli - - . Dadźbog nie stawił się też na kolejnych sesjach sądowych, co spowodowało nałożenie na niego cenzur kościelnych (tamże, k. 96v, 98). Merytoryczne rozstrzygnięcie sporu nie jest znane, por. AAG, ACons. C 2, k. 22v-38v, gdzie wyroki z lat 1462-1463. Do omawianej grupy dokumentów można też zaliczyć exceptiones (zarzuty procesowe) zgłoszone przez pełnomocnika prepozyta i konwentu w podkrakowskim Zwierzyńcu względem pisma (określonego ogólnie jako libellus) zastępcy procesowego Doroty wdowy po Macieju ze Zwierzyńca. Dokument ponownie posiada ślady po złożeniu oraz umieszczone w odpowiednich miejscach tytulik, informację o oblacie (29 V 1449) oraz notę Registrata. Dalsze przykłady takich libelli omówione zostaną przez A. K o z a k a, Fascykuł dokumentów procesowych z lat 1462-63 złożonych w konsystorzu gnieźnieńskim. Przyczynek do poznania gatunku (w przygotowaniu). 
czy też kartki z zapiskami, których brzmienie wskazuje, że mogą one być odpisami (nieuwierzytelnionymi) z ksiąg konsystorza gnieźnieńskiego. Do tego doliczyć należy akta niezwiązane bezpośrednio z działalnością konsystorza: korespondencję prywatną kanoników (m.in. listy kierowane do Stanisława Baruchowskiego), wspomniany fragment księgi wyświęconych, połowę karty, być może zawierającą fragment protokołu wizytacyjnego dekanatu Pleszew (atrybucja utrudniona jest przez stan zachowania oraz brak podobnych akt $\mathrm{z}$ tego okresu dla diecezji polskich), inwentarz relikwii z jednej z kaplic na Wawelu czy też różnego rodzaju rachunki. Wszystkie one wraz z postępem prac inwentaryzacyjnych i badawczych winny stać się przedmiotami odrębnych studiów i edycji ${ }^{37}$.

W badaniach sądowej biurokracji kościelnej nieraz sugerowano, że jej działalność musiała być związana z wytwarzaniem znacznej ilości dokumentacji ${ }^{38}$, zachowane oryginały były jednak stosunkowo nieliczne (o czym niżej). Wielką stratą w tym kontekście jest zniszczenie w 1945 r. zbioru 25000 konsystorskich dokumentów papierowych Archiwum Archidiecezjalnego w Poznaniu (Producta in consistorio Poznaniensi), na które według ks. Józefa Nowackiego składały się prezenty na beneficja, akta procesowe, pełnomocnictwa, akta komisyjne z XV-XIX w. ${ }^{39}$ Do czasów współczesnych dotarły jedynie resztki tej kolekcji, obejmujące dokumenty nowożytne (najstarszy pochodzi z 1592 r.), które i tak nie zostały po dziś dzień zinwentaryzowane ${ }^{40}$.

Dużym zbiorem oryginałów konsystorskiej dokumentacji sądowej dysponuje Archiwum Diecezjalne we Włocławku (wszelkie porównania ułatwia fakt, że jako jedno z nielicznych archiwów kościelnych posiada ono drukowane katalogi).

37 Zob. J. Ł u k a s z e w s k i, Fragmenty dwóch nieznanych druków z oficyny Jana Hallera (z 1506 i 1509 roku), Biblioteka 20 (29), 2016, s. 41-53, gdzie opisano m.in. odnaleziony w zbiorze drukowany formularz mandatu arcybiskupa Andrzeja Róży Boryszewskiego z 1509 r. (fotografie obiektu na s. 47 i 49).

${ }^{38}$ K. S t e n z e 1, Die geistlichen Gerichte zu Strassburg im 15. Jahrhundert, Zeitschrift für die Geschichte des Oberrheins 68 (NF 29), 1914, s. 383, szacuje, że kancelaria oficjalatu w Strassburgu w połowie XV w. wystawiała tygodniowo od 300 do 600 dokumentów kierowanych do duchownych (czyli wyłącznie z pierwszej grupy przyjętej wyżej klasyfikacji). Zob. też R. B e t t g e $\mathrm{n}$ h a e u s e r, Drei Jahresrechnungen des kölnischen Offizialatsgerichts in Werl 1495-1516, Annalen des Historischen Vereins für den Niederrhein 65, 1898, s. 151-201, gdzie opublikowano m.in. wykaz opłat stron za wystawione przez kancelarię dokumenty (wyroki, absolucje, zwolnienia z interdyktów, pozwy, mandaty itd.): w r. 1495 zapłacono łącznie za 330 dokumentów, w 1499 - za 253, wreszcie w 1515 - za 407. Rozliczenie to dotyczy oczywiście innej niż tu prezentowana kategorii pism konsystorskich, mianowicie dokumentów wystawianych przez sąd dla stron (przynależą więc one do archiwum odbiorcy). Niemniej $\mathrm{i}$ te liczby mogą pomóc $\mathrm{w}$ wyobrażeniu sobie skali użycia pisma w sądach kościelnych. M. K o c z e r s k a, Kancelarie konsystorskie, w: Dyplomatyka staropolska, Warszawa 2015, s. 365-367, omawiając na podstawie dotychczas znanego materiału źródłowego dokumenty wystawiane przez kancelarie konsystorskie, tylko sygnalizuje kwestię mandatów oficjalskich i właściwie pomija kwestię pism procesowych, wskazuje też ostrożnie, że zwyczaj gromadzenia $\mathrm{w}$ archiwum konsystorskich pism przedkładanych przez strony pojawił się prawdopodobnie dopiero w czasach nowożytnych.

39 J. N o w a c k i, Dzieje archidiecezji poznańskiej, t. II, Poznań 1964, s. 231.

${ }^{40}$ M. B a n a s zak, F. L e n or t, Archiwum Archidiecezjalne w Poznaniu, w: Dzieje Poznania i województwa poznańskiego (w granicach z 1974 r.). Informator o materiałach archiwalnych, t. II, Warszawa 1982, s. 239, 266. 
Składają się na nią niewystępujące w gnieźnieńskim znalezisku pergaminowe transumpty (przykłady działania konsystorza jako urzędu, a nie sądu) i wyroki wystawione przez oficjałów włocławskich (rzadziej gnieźnieńskich, poznańskich czy wrocławskich) z lat 1392-152741, a także analogiczny do pierwszej z wyróżnionych powyżej grup zespół mandatów wychodzących z konsystorza włocławskiego z lat 1428-1431 $1^{42}$. Zbiór ten jest stosunkowo liczny (ponad 100 pozycji), lecz mało różnorodny - we wszystkich przypadkach dokumenty zawierają polecenie oficjała skierowane do rektorów lub wikariuszy kościołów parafialnych, aby wezwali określone osoby do stawiennictwa przed sądem. Podobnie jak mandaty gnieźnieńskie są one opatrzone notami egzekutorów o wykonaniu. Przykłady różnego typu pism procesowych stron (trzecia grupa) odnaleźć można pomiędzy kartami ksiąg wpisów sądów kościelnych ${ }^{43}$. Przeważnie umieszczone są one tak, by uzupełniały treściowo znajdującą się w księdze zapiskę. Zachowane w ten sposób pisma są jednak stosunkowo nieliczne i nie odzwierciedlają wielkiej różnorodności tego gatunku ${ }^{44}$.

Pojedyncze oryginały dokumentów konsystorskich można znaleźć także w księgach innej proweniencji. Mandat oficjała gnieźnieńskiego Wincentego z Łagiewnik z 1507 r. skierowany do rektorów lub wikariuszy kościołów w Blizanowie, Rusowie i Rychnowie odnaleźć można w księdze grodzkiej kaliskiej, zawierającej wpisy z lat 1504-1508. Został on wykorzystany wtórnie - na niewykorzystanym przez kancelarię konsystorską odwrociu znajduje się wpis sądu grodzkiego, który omyłkowo pominięto w głównym ciągu spraw ${ }^{45}$. Z kolei na przedniej wyklejce rękopisu Digestów przechowywanego obecnie w Bibliotece Kórnickiej PAN umieszczono nieukończony odpis positionum z drugiej połowy XV w. skierowanych do J. de C. sędziego komisarycznego biskupa krakowskiego Jana (Rzeszowskiego?) ${ }^{46}$. Dokumentację związaną

${ }^{41}$ S. L i b row s ki, Inwentarz realny dokumentów Archiwum Diecezjalnego we Włocławku, t. I, Włocławek 1994, nr 196, 209-211, 215, 267, 276, 286, 294, 298, 343-345, 347, $354,358,376,382,412,452$.

${ }_{42}$ Tamże, t. III, Włocławek 1995, nr 1091-1171, 1174-1200; dodatkowo dokumenty z innych lat, por. tamże, nr 1190 (1423), 1201 (1444), 1202 (1467), 1204 (z 1479) i 1205 (1487).

${ }^{43}$ Przewodnik po zachowanych aktach sądów kościelnych stanowi tekst I. S k i e r s k i e j, Źródła do badania praktyk religijnych w średniowiecznej Polsce: akta sądów kościelnych i kapituł, Archiwa, Biblioteki i Muzea Kościelne 87, 2007, s. 175-195.

${ }^{44}$ Czysto ilustracyjnie można wskazać przykłady pism poszczególnych rodzajów. Interrogatoria: Archiwum Archidiecezjalne w Poznaniu [dalej: AAP], Dep. Test. II (1471-1478), niepaginowane wszywki między kartami $3 \mathrm{v}$ i $4,10 \mathrm{v}$ i $11,18 \mathrm{v}$ i $19,30 \mathrm{v}$ i $31,32 \mathrm{v}$ i $33,42 \mathrm{v}$ i 43, 49v, 50; AAG, ACons. B 2 (1466-1469), k. 4b, 8, 53, 62, 70, 91, 93, 95, 97, 108a, 109, $115,124,144,160,166,173,174,179,199,215,216,229$, 246. Taxaciones: AAP, AC 19 (1435), między k. 137v i 138, 173v-174; AAG, ACons. A 32 (1452), k. 119a; tamże ACons. A 33 (1453), k. 101a i 116a; tamże, ACons, A 34 (1454), k. 96 i 113. Libelli: AAG, ACons. A 30, k. 97 (1455); tamże, ACons. B 3, k. 37 (1495); Archiwum Archidiecezjalne w Przemyślu, Księga konsystorza generalnego przemyskiego, nr 2 (1482-1492), przednia karta ochronna (opis na podstawie mikrofilmu z Ośrodka Archiwów, Bibliotek i Muzeów Kościelnych, sygn. 1092). Replicationes: AAG, ACons. B 2, k. 9 (1466), 121 (1468). Articuli: AAG, ACons. B 2 (1466), k. 64. Propositio: ACons. B 2. k. 141 (1468).

45 Archiwum Państwowe w Poznaniu, Kalisz Gr. 31, k. 243.

${ }^{46}$ Biblioteka Kórnicka PAN, rękopis BK 824, k. III. Pierwszym polskim właścicielem kodeksu był Dziersław z Karnic m.in. scholastyk płocki (1456-1494) oraz tamtejszy oficjał i wikariusz generalny (1490), po jego śmierci rękopis przechowywany był dowodnie 
z sądownictwem kościelnym odnaleźć można w zbiorach Biblioteki Jagiellońskiej (częściowo są to fragmenty wydobyte z opraw rękopisów) ${ }^{47}$. Pergaminowa makulatura wyciągnięta z manuskryptów jest także źródłem informacji o praktyce dyplomatycznej czeskich sądów duchownych ${ }^{48}$.

Treść dokumentów wydawanych w związku z działalnością trybunałów kościelnych znana jest oczywiście nie tylko z oryginałów. Zachowywały się one także w formie oblat w protokołach sądowych ${ }^{49}$, a także insertów w wyrokach (przekazywały one często pełną dokumentację w danej sprawie, w tym pisma procesowe stron $)^{50}$. Najpełniejszych informacji o późnośredniowiecznej dokumentacji sądowej dostarczają jednak formularze czynności prawnych ${ }^{51}$ oraz podręczniki procesu rzymsko-kanonicznego

w bibliotece kapituły płockiej, zob. J. Z a t h e y, Katalog rękopisów średniowiecznych Biblioteki Kórnickiej, Wrocław 1963, s. 504 (opis dokumentu i proweniencji manuskryptu; W. B a r a n - K o zło w s k i, Ogólna charakterystyka oraz dzieje rękopisu „Digestum vetus cum glossis” ze Zbiorów Biblioteki Kórnickiej, Pamiętnik Biblioteki Kórnickiej 34, 2017, s. 38, w zakresie dziejów rękopisu i wklejonego dokumentu ogranicza się do sparafrazowania noty katalogowej J. Zatheya bez wyraźnego wskazania swego źródła); M. D. K ow als k i, Dlaczego warto było zostać kolektorem? Kariery papieskich kolektorów generalnych w Polsce w XV wieku, Roczniki Historyczne 80, 2014, s. 148-149 (uściślenie i uzupełnienie biogramu Karnickiego).

${ }^{47}$ Katalog zbioru dokumentów pergaminowych Biblioteki Jagiellońskiej, t. I-II, oprac. K. Nabiałek, W. Świeboda, M. Zdanek, przy współpracy R. Tatarzyńskiego, Kraków 2014, nr 57 (1391, mandat zlecający ogłoszenie ekskomuniki), 98 (ok. 1419, zeznania świadków), 182 (1462, wezwanie na sąd Mikołaja z Czechla), 189, 192, 209 (wezwania na sąd oficjała gnieźnieńskiego Piotra z Pniew z lat 1464, 1465, 1471).

48 Soudní akta konsistoře Pražské (Acta judiciaria consistorii Pragensis), t. VII: 14201424 a Dodatky, wyd. F. Tadra, Praha 1901, s. 181-246 (fragmenty akt sądowych, mandaty, procuratorium, libelli); Z. H l e dí k o vá, Několik zlomků soudních písemností z církevní praxe druhé poloviny 14 . a počátku 15 . století, Táborský archiv 12 , 2003-2004, s. 25-52 (na s. 44-52 edycje zachowanych fragmentów akt, do których inserowano propositiones, interrogatoria i depositiones).

49 Np.: Ch. S c hw a b, Das Augsburger Offizialatsregister (1348-1352), Köln-Weimar-Wien 2001, s. 217-218, 226-228, 233-234, 242-243, 250-253; zob. też akta toczących się według tej samej procedury procesów polsko-krzyżackich.

50 Archiv pražské metropolitní kapituly. t. I: Katalog listin a listů z doby předhusitské (-1419), opr. J. Eršil, J. Pražák, Praha 1956, nr 499 (1385), 502 (1385), 573 (1391); przede wszystkim na insertach zawartych w wyrokach opiera się H. J. B u d i s c h i n, Der gelehrte Zivilprozeß, s. 73-105, 169-176, gdy omawia rolę libelli i positiones w procesie rzymsko-kanonicznym.

51 Das Formelbuch des Domherrn Arnold von Protzan, wyd. W. Wattenbach, Codex diplomaticus Silesiae, t. V, Breslau 1862 (m.in. dokumenty pierwszej grupy); Formulae ad ius canonicum spectantes, ex actis Petri Wysz, episcopi Cracoviensis (1392-1412), maxima parte depromptae, wyd. B. Ulanowski, w: Scriptores rerum Polonicarum, t. XIII, Kraków 1889, s. 265-362 (m.in. dokumenty pierwszej grupy, Ulanowski pominął formuły pism procesowych stron, które odnajdował w wykorzystanych kodeksach); B. Ulanowski, Liber formularum ad ius canonicum spectantium ex actis Jacobi de Kurdwanow episcopi Plocensis maxima parte depromptarum, w: Archiwum Komisji Prawniczej, t. I, Kraków 1895 (pierwsza i trzecia grupa, pominięto liczne formuły pism procesowych znajdujące się w wykorzystanych przez wydawcę rękopisach); Liber formularum ad ius Polonicum necnon canonicum spectantium in codice Regiomontano asservatarum, wyd. B. Ulanowski, Kraków 1895 (jak w poprzednim); Formularbuch der bischöflichen Kurie von Chur aus dem 15. Jahrhundert, wyd. O. P. Clavadetscher, Chur 2003 (dokumenty pierwszej i drugiej grupy); Formularz z Uppsali. Późnośredniowieczna 


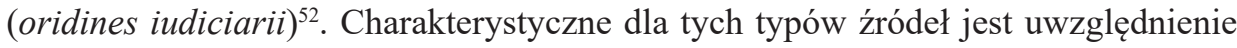
formuł dokumentów wszystkich trzech wyróżnionych w artykule grup, występują w nich często również formuły typów pism skądinąd nieznanych.

Stan zachowania akt sądów kościelnych w zachodniej Europie przedstawia dwutomowa praca The Records of the Medieval Ecclesiastical Courts, obejmująca tereny dzisiejszych Anglii, Austrii, Belgii, Francji, Hiszpanii, Holandii, Niemiec, Portugalii, Szwajcarii, Węgier i Włoch ${ }^{53}$. Choć inwentarze dla poszczególnych krajów i archiwów przygotowane zostały z różną szczegółowością, to można się jednak zorientować, że na terenach kontynentalnej Europy, tak jak i w Polsce, do czasów współczesnych dochowywały się najczęściej różnego typu księgi wpisów (akta spraw, księgi wyroków, zeznań świadków itd.). Odmienne prezentuje się sytuacja w angielskich archidiecezjach Canterbury i York, gdzie obok ksiąg sądowych zachowana jest również znaczna liczba dokumentów określanych mianem „cause papers". Definiując tę grupę, Richard H. Helmholz wskazywał, że są to papierowe bądź pergaminowe dokumenty związane $\mathrm{z}$ biegiem procesu w trybunałach kościelnych, zawierające wnioski i twierdzenia stron oraz przedstawiające działania sądu w sprawie ${ }^{54}$. Wśród typowych przykładów tego gatunku wymienia on libelli, positiones, articuli, interrogatoria, zeznania świadków czy też wyroki, a więc dokumentację gatunkowo zbliżoną do odkrytej w Gnieźnie. Podkreślić jednak należy, że - w przeciwieństwie do opisywanego znaleziska - w Anglii miała ona szczęście dotrwać do współczesności w stanie uporządkowanym, dzięki czemu pisma odnoszące się do jednej sprawy przechowywane są wspólnie ${ }^{55}$. Wydaje się, że podobnie

księga formularzowa biskupstw pruskich, wyd. R. Biskup, Toruń 2016 (m.in. dokumenty pierwszej grupy); Biblioteka Kórnicka PAN, rękopis BK 816, k. 157-161 (formuły pism procesowych stron; por. J. Z a th e y, Katalog, s. 486-493). Materiał z piętnastowiecznych formularzy oficjałów gnieźnieńskich Mikołaja Strzeszkowica i Mikołaja z Kalisza częściowo wyzyskano t. VI-XI Kodeksu dyplomatycznego Wielkopolski, wyd. A. Gąsiorowski i in., Poznań 1982-1999. Zob. też Z. H l e dí k o v á, Z diplomatické praxe pražského oficialátu ve druhé polovině 14. století, Sborník archivních prací 22, 1972, s. 135-162, gdzie informacje o księdze formularzowej używanej w konsystorzu praskim.

${ }_{52}$ W cytowanym już traktacie Mikołaja Puchníka znaleźć można formuły niemal wszystkich wykorzystywanych w procesie pism procesowych (zarówno z pierwszej, jak i trzeciej grupy), zob. D. B u d s ký, Mikuláś Puchník, s. 114-115, 122, 125-126, 128, 138, 169-170, 177-179, 182-185, 187-193, 198-201; podobny charakter ma traktat Grzegorza Snopka z Szamotuł, Processus juris breuior Joannis Andreae per Gregorium Shamotulanum juris pontificii doctorem pro tyrunculis resolutus cum practica exemplari in Regno Poloniae circa strepitum fori spiritualis observari solita, Kraków 1524 (i dalsze wydania).

${ }_{53}$ The Records of the Medieval Ecclesiastical Courts. Reports of the Working Group on Church Court Records, t. I: The Continent, t. II: England, red. Ch. Donahue Jr., Berlin 1989-1994.

${ }^{54}$ R. H. H e $1 \mathrm{~m}$ h o 1 z, Marriage Litigation in Medieval England, Cambridge 1974, s. 11-12.

55 Zob. wybrane katalogi: D. M. S m i th, Ecclesiastical Cause Papers at York: The Court of York 1301-1399, York 1988; K. M. L o n g l e y, Ecclesiastical Cause Papers at York: Dean and Chapter's Court 1350-1843, York 1980, oraz baza danych: Cause Papers in the Diocesan Courts of the Archbishopric of York, 1300-1858<https://www.dhi.ac.uk/causepapers/index. jsp>. Por. wydanie trzynastowiecznych dokumentów sądowych z archidiecezji Canterbury: Select Cases from the Ecclesiastical Courts of the Province of Canterbury, c. 1200-1301, wyd. N. Adams, Ch. Donahue Jr., London 1981. 
było początkowo także w przypadku dokumentów gnieźnieńskich - w odnalezionych w katedralnym magazynie kartonach znajdowało się kilka pergaminowych pasków mogących pierwotnie służyć do wiązania pism w wiązki, a nawet jeden cały fascykuł zbierający sześć libelli ${ }^{56}$.

Już w świetle wstępnych ustaleń nie ulega wątpliwości wielka wartość historyczna dokumentów odnalezionych w katedrze gnieźnieńskiej. O niezwykłości omawianego znaleziska stanowi chociażby jego wielkość oraz fakt, że występują w nim akta dotychczas rzadko spotykane w postaci oryginałów. Powoduje to, że zbiór nie posiada bliższych analogii w kolekcjach polskich archiwów kościelnych, a spośród archiwaliów zagranicznych porównać go można jedynie z angielskimi „cause papers”. Zauważyć wypada również, że odnaleziona dokumentacja znakomicie uzupełnia przechowywany w Archiwum Archidiecezjalnym w Gnieźnie zespół ponad 80 późnośredniowiecznych ksiąg wpisów tamtejszego konsystorza arcybiskupiego. Wspólnie pozwolą one odtworzyć dokładny obraz piętnastowiecznej biurokracji i kościelnego wymiaru sprawiedliwości. Nie ulega też wątpliwości, że dokładna inwentaryzacja i szczegółowe badania znaleziska winny przynieść kolejne ustalenia i pozwolą na uściślenie bądź zweryfikowanie przedstawionych tu twierdzeńn ${ }^{57}$.

\section{ANEKS}

Niniejsza edycja została przygotowana do druku zasadniczo według zasad sformułowanych we wstępie t. VI Kodeksu dyplomatycznego Wielkopolski (wyd. A. Gąsiorowski i H. Kowalewicz, Warszawa-Poznań 1982, s. XIII-XVIII) oraz zaleceń A. Wolffa, Projekt instrukcji wydawniczej dla pisanych źródeł historycznych do połowy XVI wieku, Studia Źródłoznawcze 1, 1957, s. 155-181. Liczba kropek w nawiasach kwadratowych odpowiada w przybliżeniu liczbie brakujących w ubytku liter. Przypisy rzeczowe ograniczono do identyfikacji miejscowości (wskazano współczesną nazwę oraz staropolską przynależność powiatową i parafialną; przy lokalizacji wykorzystano głównie bazę danych: Ziemie polskie Korony w XVI w. Przestrzenna baza danych, Instytut Historii PAN im. Tadeusza Manteuffla 2015-, <http://atlasfontium.pl/index. php?article=korona $>$ ) oraz ważniejszych dostojników duchownych i świeckich (w celu sprawdzenia, czy dane podane przez dokument są zgodne z rzeczywistością).

\section{1.}

[b.m.w., tuż przed lub w sam dzień 1 X 1445] Petnomocnik Dobiesława z Chyszowa i Piotra z Dabrówki prepozyta tarnowskiego, kolatorów kościoła parafialnego w Zbylitowskiej Górze oraz Macieja syna Benedykta ze Strzeszewa, prezentowanego przez nich na wspomniany kościót, zwraca się do Mikołaja z Kalisza wikariusza in spiritualibus, oficjała generalnego gnieźnieńskiego

${ }^{56}$ A. K o z a k, Fascykuł dokumentów procesowych (w przygotowaniu).

57 Będzie to jednym z zadań pracującego niezależnie od autorów niniejszego tekstu zespołu grantowego „Inwentaryzacja zasobu Archiwum Archidiecezjalnego w Gnieźnie: starodruki z Kolekcji Seminaryjnej Biblioteki Katedralnej i nowo odnalezione dokumenty papierowe konsystorza gnieźnieńskiego z XV i pocz. XVI w." (Narodowy Program Rozwoju Humanistyki, nr 11H 160124 84, kierownik: dr Piotr Pokora), którego prace potrwają do 2022 r. 
i sędziego sprawy apelacyjnej tychże z Mikołajem Brzechwa ze Zbylitowskiej Góry i Janem Rokoszem z Koszyc, roszczacymi sobie prawo patronatu do kościoła w Zbylitowskiej Górze oraz prezentowanym przez nich Mikołajem z Trzemeśni, o wydanie wyroku przedstanowczego, unieważniającego zlecenia przestuchania świadków przez komisarza Dziersława Borzymowskiego archidiakona krakowskiego oraz niedopuszczenie do sprawy protokołów ich zeznań.

Or.: AAG, bez sygnatury. Papier $185 \times 220 \mathrm{~mm}$ (po złożeniu $30 \times 220 \mathrm{~mm}$ ). Na stronie verso pod tekstem głównym noty pisane różnymi rękoma: 1. Oblat(um) die Veneris prima mensis Octobris anno Domini $\mathrm{M}^{\circ} \mathrm{CCCC}^{\circ} \mathrm{XL}^{\circ}$ quinto (nota o przedtożeniu dokumentu sadowi); 2. Protestacio procuratoris cum racionibus de non recipiendo rotulo domini Burzynowsky (tytulik dokumentu pisany pismem o większym module, widoczny po złożeniu dokumentu); 3. R(egistra)ta.

Protestatur procurator ante omnia nomine procuratorio nobilis ac honorabilis virorum, dominorum Dobeslai de Chyschow ${ }^{1}$ et Petri prepositi Tharnowiensis ${ }^{a-}$ de Dambrowa ${ }^{-b 2}$, heredum et patronorum ${ }^{c-c}$ ecclesie in Gora $^{3}$ et Mathie Benedicti ${ }^{d}$ de Strzeschew ${ }^{e 4}$ Cracouiensis dyocesis, quod in apercionem cuiusdam pretenti rotuli seu attestacionum pro parte nobilium virorum, dominorum Nicolai Brzechwa de Gora, Johannis Rocosz de Costrzicze ${ }^{5}$, ex adverso preten(torum ${ }^{d}$ patronorum dicte ecclesie in Gora necnon Nicolai de Trzemeszna ${ }^{6}$ presbiteri Gneznensis dyocesis ad eandem ecclesiam in Gora preten(ti) presentati in vim remissionis Vestre Venerabilitatis in personam venerabilis viri, domini Derslai Borzynowsky archidiaconi Cracouiensis ${ }^{7}$ decrete $^{f}$ productorum excipitque dictus procurator et excipiendo dicit:

Et primo pro eo dicta remissio et rotulus attestacionum non valet nec per vos recipi aut admitti deberet, quia in actis consistorii vestri contineret, quod ipsa pars adversa expedita in tempore dicta remissione una cum articulis obiectivis pretentis sigillatis ipsam remissionem coram venerabili domino Derslao Burzynowsky comissario examinis testium prosequi non curavit neque eandem remissionem iuxta continenciam actorum prima die iuridica post vaccaciones seu ferias versus Gneznam Vestre Venerabilitati reportavit, prout se idem procurator in eisdem actis obligavit. Et quamvis per vos instant(er) dicto procuratore partis adverse ipsa remissio fuisset validata ad quindenam, nichilominus tamen infra dictum terminum seu eciam in terminis per ipsam partem adversam non fuit dicta remissio et rotulus attestacionum reportatus, propter quod ipsa pretenta remissio non est admittenda.

Item dicta remissio una cum rotulo attestacionum per vos recipi non deberet ex eo, quia eadem remissio, vigore cuius testes pro parte supradictorum dominorum Nicolai Brzechwa, Johannis Rocosz necnon Nicolai eorum presentati super quibusdam articulis pretentis obiectivis inducti, fuit per vos cassata et annulata, prout ex actis Vestre Venerabilitatis manifeste apparet, que acta hic inserit et habere wlt pro insertis, nam apparet evidenter ex eisdem actis, quia procurator partis adverse in eandem cassacionem et anullacionem dicte pretente remissionis non allegata aliqua diligencia et impedimento, propter que dictam remissionem non fuisset prosecutus, tacite consensit neque ab eadem interlocutoria stante decendio aliquam protestacionem de appellando fecit, prout hoc ex actis colligi potest. Et sic eadem interlocutoria transivit in rem iudicatam. Constat enim dictum procuratorem partis adverse in eandem 
cassacionem remissionis et aliorum inde secutorum consensisse ex eo, quia alium actum faciendo, iudices videlicet, venerabiles dominos Johannem Helgoth scolasticum Cracoviensem ${ }^{8}$, Andream Myszka scolasticum Gneznensem ${ }^{9}$, super examine et recognicione sigilli olim domini Alberti episcopi Cracoviensis ${ }^{10}$ eligendo ${ }^{g}$, peciit actumque precedentem per hoc ratum et gratum habuit. Igitur ad appercionem dicti pretenti rotuli seu attestacionum procedere non potestis, sed duntaxat ac ad recognicionem supradicti sigilli et littere alternacionis et consequenter ad conclusionem cause procedere debetis, attento eciam eo, quod actis contravenire non potestis.

[Verso] Petit igitur $^{h-h}$ procurator predictus, qui supra, per vos venerabilem dominum Nicolaum decretorum doctorem, vicarium in spiritualibus et officialem generalem ecclesie Gneznensis, iudicem cause appellacionis vestramque sentenciam interlocutoriam pronunciari, decerni et declarari dictam pretentam remissionem pro parte dictorum dominorum Nicolai Brzechwa, Johannis Rocosz et Nicolai de Trzemeszna eorundem presentati in personam venerabilis domini Derslai Burzynowsky archidaconi Cracouiensis decretam fuisse et esse per vestram interlocutoriam sentenciam verbo cassatam, annulatam et irritatam ac in rem transivisse iudicatam, et ob hoc dictam remissionem et rotulum attestacionum racione dicte cassacionis et irritacionis per vos non esse recipiendum, sed pocius repellendum fore et repelli debere, in eademque causa ad conclusionem dicte cause procedendum fore et procedi debere vestra sentencia interlocutoria iusta mediante. Salvo iure addendi, minuendi, corrigendi etc. Petit expensas in huiusmodi lite negocio factas et protestatur de faciendis.

${ }^{a-b}$ Dopisane na górnym marginesie. $\quad{ }^{c}$ Następuje skreślone: ecclesie. $\quad{ }^{d}$ Dopisane między wierszami. ${ }^{e}$ Poprawiono z: Strzeszewo. ${ }^{f}$ Poprawiono z: decre. ${ }^{g}$ Dopisane w miejscu skreślonego: elegit et. ${ }^{h}$ Następuje skreślone: dictus.

${ }^{1}$ Chyszów (obecnie część Tarnowa), pow. pilzneński w Małopolsce, par. Zbylitowska Góra. ${ }^{2}$ Najpewniej Dabrówka Infułacka (obecnie część Tarnowa), pow. pilzneński, par. Zbylitowska Góra. $\quad{ }^{3}$ Zbylitowska Góra, pow. pilzneński, par. własna. $\quad{ }^{4}$ Strzeszew, Strzeszewo, Strzeszów itp., liczne miejscowości o tej nazwie. ${ }^{5}$ Najpewniej Koszyce Wielkie lub Koszyce Małe, pow. pilzneński par. Zbylitowska Góra. $\quad{ }^{6}$ Trzemeśnia, pow. pilzneński, par. Łękawica. ${ }^{7}$ Dzierstaw z Borzymowa (pow. wiślicki, par. Oleśnica), archidiakon krakowski 1435-1450 (T. Graff, Ks. Dziersław Borzymowski CRL w stużbie państwa polskiego i Kościoła, w: Klasztor Bożego Ciała Kanoników Regularnych Laterańskich w Krakowie w okresie przedtrydenckim, Łomianki 2012, s. 157-176). $\quad{ }^{8}$ Jan Elgot z Lgoty, scholastyk krakowski 1439-52 (H. Barycz, Elgot Jan, w: Polski stownik biograficzny, t. VI, Kraków 1948, s. 227-228). ${ }^{9}$ Andrzej Myszka z Nieprześni, scholastyk gnieźnieński 1426-46 (M. Czyżak, Kapituła katedralna w Gnieźnie $w$ świetle metryki z lat 1408-1448, Poznań 2003, s. 316). ${ }_{10}^{10}$ Wojciech Jastrzębiec, biskup krakowski 1412-1423, następnie arcybiskup gnieźnieński 1423-1436.

2.

Żerniki, 12 VIII 1451

Andrzej i Jan dziedzice w Żernikach prezentują Władysławowi Oporowskiemu arcybiskupowi gnieźnieńskiemu badź jego wikariuszowi in spiritualibus Stanisława syna Franciszka plebana w Żernikach na kościót parafialny $w$ Łopiennie i filialny w Gaczu. Or.: AAG, ACons. H 37. Pergamin $225 \times 115+13$ mm. Drobne ubytki w tekście spowodowane przedarciami pergaminu. Do dokumentu przywieszone byty dwie pieczęcie, śladem po pierwszej jest nacięcie zakładki, po drugiej - pergaminowy 
pasek. Na odwrociu nota o przedłożeniu dokumentu sądowi: 1452 die Veneris XXIIII Marcii oblat(um).

Reverendissimo in Christo patri et domino, domino Vladislao Dei gracia sacrosancte metropolitane Gneznensis eclesie archiepiscopo et primati ${ }^{1}$, domino nobis graciosissimo aut eius in spiritualibus vicario generali ${ }^{2}$, Andreas et Johannes fratres germani, heredes in Zyrniky ${ }^{3}$ filialem obedienciam reverencie cum exibicione. Reverendissime pater et domine, domine graciosissime! Quia eclesia in Lopyenno ${ }^{4}$ tamquam mater et in Gandecz ${ }^{5}$ velut filia per mortem discreti Johannis ultimi rectoris earumdem eclesiarum et immediati vacat ad presens, quarumquidem eclesiarum ius patronatus et presentandi iure hereditario nos concernit, ideo Paternitati Vestre discretum Stanislaum Francisci de Janyczewo ${ }^{6}$ plebanum modernum in Zyrniky vestre dyocesis, videlicet presencium cursorem, vita laudabili, probitate virtutum honestaque conversacione decoratum, duximus presentandum ac presentamus eum et pro eo attencius supplicantes, quatenus Vestra Paternitas pre[fatum Sta]nislaum ad memoratas eclesias dignetur instituere et investire graciose, curam animarum administracionemque spiritualium sibi et temporalium in eisdem committentes, veluti ad vestrum pertinet officium pastorale. In cuius rei testimonium sigilla nostra presentibus sunt subappensa. Datum in Zyrniky feria quinta ante Assumcionem Marie Virginis Gloriose de anno Domini millesimo quadringentesimo quinquagesimo primo etc.

${ }^{1}$ Władysław Oporowski, arcybiskup gnieźnieński 1449-1453. $\quad 2$ Sędziwój z Czechla (pow. kaliski, par. Kucharki), wikariusz in spiritualibus gnieźnieński 1449-1453 (A. Gąsiorowski, I. Skierska, Średniowieczni oficjałowie, s. 84). $\quad{ }^{3}$ Żerniki, dawne miasto, pow. kcyński, par. własna. ${ }^{4}$ Łopienno, pow. gnieźnieński, par. własna. ${ }^{5}$ Gącz, pow. gnieźnieński, par. Łopienno, nastepnie par. własna. ${ }^{6}$ Zapewne Juncewo, pow. kcyński, par. własna.

\section{3.}

Gniezno, 30 IX 1[4]54 Mikołaj z Czechla kanonik i oficjał gnieźnieński poleca wikariuszowi kościoła parafialnego $w$ Sobótce wezwać Piotra plebana tamże, aby stawit się $w$ oznaczonym terminie przed oficjałem w Gnieźnie na rozprawie z Piotrem Bardzkim kanonikiem gnieźnieńskim.

Or.: AAG, ACons. H 102. Papier $215 \times 74 \mathrm{~mm}$. Na odwrociu dwie noty pisane różnymi rękoma wzdtuż krótszego boku dokumentu: 1. Per me Petrum vicarium in Sobothka facta est execucio presentis mandatis feria sexta post dominicam, qua decantatur in ecclesia „Miserere mihi Domine” [11 X 1454], et citavi eundem dominum Petrum plebanum personaliter apprehensum in domo habitacionis, et in signum huiusmodi execucionis me manu propria subscripsi (nota o wykonaniu mandatu); 2.1454 die Mercurii XXIII Octobris citatus non comparens pronunciatur contumacem (nota o przedłożeniu dokumentu sądowi; po słowie die skreślono ve). Poniżej odcisk pieczęci sygnetowej $w$ technice wosk przez papier, gdzie wewnattrz zatartego otoku dobrze widoczny herb Korab Mikołaja z Czechla.

Nicolaus de Czyechel licenciatus in decretis, canonicus et officialis sancte ecclesie Gneznesis generalis ${ }^{1}$ discreto viro ${ }^{a-a}$ vicario ecclesie parrochalis in Sobotha ${ }^{2}$ aliisque 
presentibus requirendibus salutem in Domino! Mandavimus vobis in virtute sancte obediencie et sub excommunicacionis pena, quatenus personaliter accedentes, uno edicto pro tribus et peremptorie, citetis honorabilem dominum Petrum plebanum in ibidem Sobotha, quem presentibus nos citamus, ut coram nobis Gnezne in domo habitacionis nostre ${ }^{b-b}$ nona die, a die execucionis sive citacionis presencium, si ipsa nona dies iuridica fuerit, alias prima die iuridica ex tunc immediate sequente, hora terciarum legitime compareat ad instanciam venerabilis domini Petri Barthsky canonici ecclesie Gneznensis ${ }^{3}$, pro et super certis iniuriis, alias ad que ius obiciens iudicialiter ${ }^{c-c}$ responsurus. Datum Gnezne die Lune ultima mensis Septembris anno Domini $\mathrm{M}^{\circ}$ etc. L quarto, nostro sub sig(illo). Litteram reddatis debite executam, d(ie) annotat(a).

${ }^{a}$ Nastęuje skreślone: rectori et. $\quad{ }^{b}$ Następuje skreślone: fer. $\quad{ }^{c}$ Następuje powtórzone: iudicialiter.

${ }^{1}$ Mikołaj z Czechla (pow. kaliski, par. Kucharki), kanonik gnieźnieński 1453-1464, oficjat tamże 1452-1454 oraz 1457-1464, wikariusz in spiritualibus tamże 1457-1464 (A. Gąsiorowski, I. Skierska, Średniowieczni oficjałowie, s. 84). $\quad{ }^{2}$ Zapewne Sobótka (zob. nota o wykonaniu mandatu w uwadze), pow. kaliski, par. własna, ewentualnie pow. łęczycki, par. własna. 3 Piotr z Barda (pow. pyzdrski, par. własna), kanonik gnieźnieński 1454-1468 (P. Dembiński, Poznańska kapituła katedralna schyłku wieków średnich. Studium prozopograficzne 14281500, Poznań 2012, s. 614-615).

\section{4.}

[b.m.w., tuż przed lub w sam dzień 23 VI 1462] Pełnomocnik Andrzeja wicekustosza włocławskiego zwraca się do Mikołaja z Czechla oficjała generalnego gnieźnieńskiego i sędziego w sprawie apelacyjnej tegoż Andrzeja z Dadźbogiem ze Szpiegowa stolnikiem dobrzyńskim o zasądzenie od Dadźboga na rzecz Andrzeja 2 kóp groszy zaległej dziesięciny snopowej z ról folwarcznych w Szpiegowie stanowiacych uposażenie kustodii włocławskiej.

Or.: AAG, bez sygnatury. Papier $219 \times 135 \mathrm{~mm}$. Drobne ubytki w tekście spowodowane przez poszarpanie dolnej krawędzi dokumentu i kilka niewielkich dziur. $\mathrm{Na}$ stronie verso pod tekstem głównym dwie noty pisane różnymi rękoma: 1. 1462 die Mercurii XXIII Junii oblat(um) (nota o przedłożeniu dokumentu sadowi); 2. Libellus convencionalis summarius pro parte domini Andree vicecustodis ecclesie Wlad(islaviensis) contra nobilem Dadzybogium de Szpyegowo dyocesis Wlad(islaviensis) (tytulik dokumentu pisany pismem o większym module).

Coram vobis venerabili viro, domino Nicolao de Czechel licenciato in decretis canonicoque, vicario in spiritualibus ac officiali Gneznensis ecclesie generali ${ }^{1}$, iudice appellacionis cause et partibus infrascriptis procurator et nomine procuratorio honorabilis viri, domini Andree vicecustodis ecclesie Wlad(islaviensis) dyocesis [sic!] contra et adversus nobilem Dadzybogium dapiferum Dobrinensem ${ }^{2}$ dicte dyocesis et contra quamlibet aliam personam pro eo vestro in iudicio legittime intervenientem, gravi cum querela proponit atque dicit, quod quamvis ab annis et temporibus retroactisque legittime prescriptis, quorum memoria hominum vivencium in contrarium non existit, nonnulli antecessores predicti nobilis Dadzybogii pro tempore existentes 
ac ipse nobilis Dadzybogius heres modernus de dicta sua hereditate in Szpyegowo ${ }^{3}$ racione decime manipularis post agros prediales seu alodiales quomodolibet annis singulis provenientis domino vicecustodi pro tempore existenti racione fundi custodie necnon serviciorum suorum, que peragit in ipsa ecclesia Wlad(islaviensi), unum fertonem peccuniarum solvebant pro annis singulis ac solvere consueverunt et idem nobilis Dadzybogius post eos successive, in cuius fertonis peccuniarum possessione idem domini vicecustodes et dictus dominus Andreas modernus vicesustos fuissent et extitissent pacifica seu quasi et quieta absque quavis contradiccione, nichilominus tamen prefatus nobilis Dadzybogius in Szpyegowo [heres] nescitur quo ductus spiritu $^{a-a}$ aut qua inco[ntinencia] permotus huiusmodi fertonem peccuniarum de decem annis iam transactis seque continue et immediate sequentibus eidem domino Andreee vicecustodi dare et solvere neglexitque recusat et contradicit in non modicum eiusdem domini A(ndree) vicecustodis preiudicium, iacturam ac gravamen, in dispendium salutis proprie ac scandalum non modicum christifidelium plurimorum.

Quare petit procuratur predictus nomine procuratorio, quo supra, per vos venerandum dominum iudicem appellacionis ac vestram sentenciam diffinitivam iustam et sanctam pronunciari, decerni ac declarari prefatumque nobilem Dadzybogium in decem ferthonibus peccuniarum et in summa duarum sexagenarum ipsi domino Andree vicecustodi racione [suorum] serviciorum, sic ut $\operatorname{prefertur}^{b-b}$, $\operatorname{retardat(is)~ac~}$ retar[....... que per eum retentarum obligatum fuisse et extitisse, eosdem de decem annis successive solvere recusasse $[\ldots . . . . .$.$] , contradixisse sibique talia facere non$ licuisse [neque licere], [verso] et ob hoc prefatum nobilem Dadzybogium ad dandum et solvendum huiusmodi duas sexagenas peccuniarum taliter retentarum eidem domino Andree vicecustodi condempnandum et compellendum fore per vosque cogi et compelli debere una cum expensarum condemnacione in huiusmodi causa ac lite factarum ac super ulterioribus vexacionibus, perturbacionibus molestacionibusque retencionibus ac eorum occasione eidem nobili Dadzybogio perpetuum silencium imponendum fore ac per vos imponere debere vestra sentencia diffinitiva iusta ac sancta mediante, vestrum benignum officium super hoc humiliter implorando.

Salvo iure addendi, minuendi, corrigendi ceterisque iuris beneficiis per omnia sibi semper salvis.

${ }^{a}$ Następuje skreślone: at. $\quad{ }^{b}$ Następuje skreślono: det.

${ }^{1}$ Por. nr 3 przyp. 1. $\quad{ }^{2}$ Dadźbog ze Szpiegowa (ziemia dobrzyńska), notowany jako stolnik dobrzyński w latach 1464-1482, jego poprzednik ostatni raz poświadczony jest w 1457 (Urzędnicy kujawscy i dobrzyńscy XII-XV wieku. Spisy, oprac. J. Bieniak, S. Szybkowski, Kórnik 2014, s. 281). $\quad{ }^{3}$ Zob. przyp. 2.

5.

Gniezno, 17 II 1490

Jan z Goślubia prepozyt, wikariusz in spiritualibus i oficjał generalny gnieźnieński zleca Tomaszowi oficjałowi kamieńskiemu i Grzegorzowi plebanowi w Dużej Cerkwicy przesłuchanie świadków, których wskaże Stanisław pleban w Tucholi, w jego sporze z tamtejszymi burmistrzami Jakubem Jedleńskim i Jakubem Granowskim oraz rajcami Maciejem Bykała, Janem Sroderem, Hannusem Happa i Michałem kowalem, a nastęnie odesłanie w terminie jednego miesiąca protokołów zeznań do Gniezna. 
Or.: AAG, ACons. H 106. Papier $322 \times 132$ mm. Pod tekstem pieczęć w technice wosk przez papier; w zatartym otoku dobrze widoczny herb Sulima Jana z Goślubia. Na odwrociu nota odbiorcy: 1490. Die Veneris decima nona mensis Marcii oblat(um) in Camyen coram nobis iudicibus deputatis per honorabilem dominum Simonem prepositum Sancte Elizabeth extra muros Thucholienses portitorem rotuli cum litteris remissionum super examinandos testes reverendi patris, domini Joannis de Goslub etc. officialis Gneznensis generalis, qui dicebat se in manibus [sic!] notariorum Sue Paternitatis iuramentum de fidelitate delacione corporale prestitisse. Et ibidem honorabilis dominus Stanislaus plebanus de Thuchola personaliter comparens, petivit procedi ad execucionem litterarum remissorialium. Et nos iudices intro contenti decrevimus litteras citacionum contra preconsules et consules ac testes inducendos contra ipsos, presentibus discretis Blasio vicario et Mathia ministro ecclesie in Camyen, testibus circa premissa. Ego Thomas plebanus et officialis Camyensis in defectu notarii scripsi manu mea propria in presencia mei college Gregorii de Czirqwicza plebani.

Johannes de Goslub decretorum doctor, prepositus Gneznensis vicariusque in spiritualibus et officialis generalis ${ }^{1}$ honorabilibus viris, dominis Thome officiali Camenensi ${ }^{2}$ et Gregorio plebano in Czirquicza ${ }^{3}$, fratribus dilectis salutem et fraternam in Domino caritatem coniu(n)ctim! Pridem orta coram nobis causa ordinaria inter honorabilem et providos Stanislaum plebanum ex una et Jacobum Jedlensky, Jacobum Granowsky proconsules, Mathiam Bykala, Johannem Sroder, Hannus Happa et Michaelem fabrum consules opidi Tuchola ${ }^{4}$ ex altera partibus, pro, de et super certis iniuriis ipsi domino Stanislao plebano et sue eclesie illatis, in quaquidem causa, postquam cum dictarum parcium procuratoribus ad nonnullos actus terminosque iudiciarios gradatim et successive usque ad productionem hincinde libellorum et eorum loco articulorum reproductionem ipsorumque admissionem et responsionem processissemus, tandem die inferius annotata coram nobis iudicio pro tribunali presidentibus, comparens personaliter circumspectus magister Gregorius de Camyenyecz ${ }^{5}$ causarum consistorii Gneznensis et dicti domini Stanislai plebani legitimus procurator, de cuius procuracionis mandato apud acta cause huiusmodi per legitima constat documenta, exposuit, quomodo testes ad probandum sue partis articulos propter longam loci distanciam, graves quoque sumptus, fatigas et expensas, versus locum et civitatem Gneznensem comode inducere non possit, propter quod nobis debita cum instancia supplicavit, quatenus vobis examen et recepcionem huiusmodi testium committere dignaremur. Nos tunc attendentes peticionem huiusmodi fore iustam et racioni consonam, prepetitas nostras commissionis sive remissionis litteras in forma solita et fieri consueta decrevimus fore dandum damusque et decernimus per presentes, hortantes vos in Domino, quatenus vocatis ad vestri presenciam testibus, quos dictus Stanislaus plebanus in Tuchola aut suus procurator inducere voluerit, ipsos in presencia partis adverse ad hoc legitime citate et alias in contumaciam recipiatis secundumque tenorem libelli convencionalis articulati et interrogatoriorum, que vobis cum presentibus claus(a) dirigimus, secundum prudenciam vobis a Domino Deo datam, adhibito vobis aliquo notario publico fideli et legali, examinetis et examinare curetis, recepto primitus a quolibet testium de dicenda veritate corporali iuramento. Attestaciones vero sive dicta testium in uno volumine conscript(a) vestris sigillis consignatis et alias modo, 
forma et stilo talibus dispositis, clausis, ligatis, ita quod ipsis aput nos in iudicio et extra fides valeat adhiberi, nulli parcium attestacionibus publicatis, nobis versus locum et civitatem Gneznensem per aliquem nuncium iuratum, idoneum et fidelem infra spacium unius mensis dirigatis et dirigere curetis, ne veritas cause valeat deperiri. Testes vero, qui nominati fuerint, si se gracia, odio, timore, pre(ce) aut precio subtraxerint, per censuram ecclesiasticam rogatis testimonium veritati perhibere. Datum Gnezne die decima septima mensis Februarii anno Domini millesimo quadringentesimo nonagesimo, nostro sub sigillo.

${ }^{1}$ Jan z Goślubia (pow. tęczycki, par. Piątek), prepozyt gnieźnieński 1483-1500, oficjał i wikariusz in spiritualibus tamże 1484-1500 (A. Gasiorowski, I. Skierska, Średniowieczni oficjałowie, s. 84). 2 Oficjałowie kamieńscy z lat 1456-1502 sq skądinąd nieznani (A. Gąsiorowski, I. Skierska, Oficjalaty okręgowe, s. 120; ciż, Początki oficjalatu kamieńskiego archidiecezji gnieźnieńskiej [wieki XIV-XV], Kwartalnik Historyczny 103, 1996, 2, s. 20). ${ }^{3}$ Duża Cerkwica, pow. tucholski, par. własna. ${ }^{4}$ Tuchola, miasto, pow. tucholski, par. własna. ${ }^{5}$ Kamieniec, liczne miejscowości o tej nazwie.

6.

[II połowa $X V$ w.]

Jan Kaliszkowski, Jan i Mikołaj Ciesielscy oraz Mikołaj Lewkowski jako świadkowie zeznaja w sprawie zwrotu 20 grzywien dtugu Piotrowi Pacanowskiemu mieszczaninowi gnieźnieńskiemu przez szlachetnego Jana Szadkowskiego.

Or.: AAG, ACons. H 451. Papier $190 \times 210 \mathrm{~mm}$. Strona verso pozbawiona not. Dokument niedatowany, pisany ręa z II pot. XV w. Wspomniany $w$ tekście Jan z Kaliszkowic Kaliskich (pow. ostrzeszowski, par. Kottów) wzmiankowany jest w r. 1458, Jan z Szadka (pow. kaliski, par. Pamięcin) występuje w latach 1459-1495, Mikołaj z Lewkowa (pow. kaliski, par. własna) notowany jest $w$ latach 1469-1497, wreszcie Mikołaja z Cieśli (pow. kaliski, par. Kajew) wspomniano w r. 1481 (Stownik historyczno-geograficzny ziemi wieluńskiej w średniowieczu, oprac. R. Rosin, Warszawa 1963, s. 88; Kartoteka Stownika Historyczno-Geograficznego Wielkopolski w Poznaniu).

${ }^{a-T e s t e s ~ i n d u c t i ~ p r o ~ p a r t e ~ n o b i l i s ~ d o m i n i ~ J o h a n n i s ~ S z a d k o w s k y ~ e t c . ~}{ }^{-b}$

Testes infrascripti de generalibus et specialibus in forma iuris diligenter interrogati aliisque de iure servandis premissis unusquisque sub debito consciencie sue deposuit, ut supra:

Primus testis, nobilis Johannes Kalyschkowsky etc. interrogatus de solucione viginti marcarum Petro Paczanowsky debitas per nobilem Johannem Szadkowsky, respondit testis, quod presens fuit, vidit, quod dictus Johannes Szadkowsky dictas viginti marcas Petro Paczanowsky ad huc in humanis agenti in villa Szyrnyky ${ }^{1}$ in districtu Calisiensi realiter et cum effectu solvit.

Secundus testis, nobilis Johannes Czyeszelsky interrogatus de et super solucione viginti marcarum etc., qui testis respondit, quod vidit et presens fuit, quando J[ohannes] Szadkowsky P[et]ro Paczanowsky solvit viginti marcas in villa Szyrnyky, que villa fuit olim N. Raczkowsky, cuius ipse tunc familiaris fuit etc.

Tercius testis, nobilis Nicolaus Czyeszelsky de et super solucione viginti marcarum, ut supra etc., interrogatus respondit, quod vidit et fuit presens, dum nobilis 
Johannes Szadkowsky Petro Paczanowsky viginti marcas debitas realiter et cum effectu solvit in villa Szyrnyky etc.

Quartus testis, nobilis Nicolaus Lewkowsky de et super solucione viginti marcarum etc. interrogatus, respondit, quod audivit et scit ex fama, quod nobilis Johannes Szadkowsky olim Petro Paczanowsky civi Gneznensi viginti marcas sibi debitas solvit.

${ }^{a-b}$ Zapisano pismem o większym module.

${ }^{1}$ W pow. kaliskim odnotowane sa dwie wsie o nazwie Żerniki, jedna w par. Kretków, druga w par. Blizanów, w żadnej nie jest odnotowany szlachcic Raczkowski (Kartoteka Stownika Historyczno-Geograficznego Wielkopolski w Poznaniu).

\section{BIBLIOGRAFIA}

Aleksandrowicz M., Źródła rękopiśmienne do dziejów archidiecezji gnieźnieńskiej w Archiwum Archidiecezjalnym w Gnieźnie, w: 1000 lat Archidiecezji Gnieźnieńskiej, Gniezno 2000.

Aleksandrowicz M., Rył J., Zientarski W., Archiwum Archidiecezjalne w Gnieźnie, w: Dzieje Poznania i Województwa Poznańskiego (w granicach z 1974 r.). Informator o materiałach archiwalnych, t. 2, Warszawa 1982.

Banaszak M., Lenort F., Archiwum Archidiecezjalne w Poznaniu, w: Dzieje Poznania i województwa poznańskiego (w granicach z 1974 r.). Informator o materiałach archiwalnych, t. II, Warszawa 1982.

Barycz H., Elgot Jan, w: Polski słownik biograficzny, t. VI, Kraków 1948.

Bettgenhaeuser R., Drei Jahresrechnungen des kölnischen Offizialatsgerichts in Werl 14951516, Annalen des Historischen Vereins für den Niederrhein 65, 1898.

Biskup M., Tomczak A., Mapy województwa pomorskiego w drugiej połowie XVI w. Rozmieszczenie własności ziemskiej, sieć parafialna, Toruń 1955.

Budischin H.J., Der gelehrte Zivilprozeß in der Praxis geistlicher Gerichte des 13. und 14. Jahrhunderts im deutschen Raum, Bonn 1974.

Budský D., Mikuláš Puchník. Život a právnické dílo, Praha 2016.

Czyżak M., Kapituła katedralna w Gnieźnie w świetle metryki z lat 1408-1448, Poznań 2003.

Dembiński P., Poznańska kapituła katedralna schyłku wieków średnich. Studium prozopograficzne 1428-1500, Poznań 2012.

Donahue Jr. Ch., The Ecclesiastical Courts: Introduction, w: The History of Courts and Procedure in Medieval Canon Law, Washington 2016.

Formularbuch der bischöflichen Kurie von Chur aus dem 15. Jahrhundert, wyd. O.P. Clavadetscher, Chur 2003.

Formularz z Uppsali. Późnośredniowieczna księga formularzowa biskupstw pruskich, komentarz i edycja R. Biskup, Toruń 2016.

Gąsiorowski A., Notariusze publiczni w Wielkopolsce schyłku wieków średnich, Poznań 1993.

Gąsiorowski A., Skierska I., Oficjalaty okręgowe w późnośredniowiecznej archidiecezji gnieźnieńskiej, Czasopismo Prawno-Historyczne 47, 1995, z. 1-2.

Gąsiorowski A., Skierska I., Początki oficjalatu kamieńskiego archidiecezji gnieźnieńskiej (wieki XIV-XV), Kwartalnik Historyczny 103, 1996, nr 2.

Gąsiorowski A., Skierska I., Średniowieczni oficjałowie gnieźnieńscy, Roczniki Historyczne 61, 1995.

Graff T., Ks. Dziersław Borzymowski CRL w służbie państwa polskiego i Kościoła, w: Klasztor Bożego Ciała Kanoników Regularnych Laterańskich w Krakowie w okresie przedtrydenckim. Ludzie - Wydarzenia - Kultura, Łomianki 2012.

Helmholz R.H., Marriage Litigation in Medieval England, Cambridge 1974.

Hledíková Z., Několik zlomků soudních písemností z církevní praxe druhé poloviny 14. a počátku 15. století, Táborský archiv 12, 2003-2004. 
Hledíková Z., Z diplomatické praxe pražského oficialátu ve druhé polovině 14. století, Sborník archivních prací 22, 1972.

Katalog zbioru dokumentów pergaminowych Biblioteki Jagiellońskiej, t. I-II, opr. K. Nabiałek, W. Świeboda, M. Zdanek, przy współpracy R. Tatarzyńskiego, Kraków 2014.

Knapek E., Akta oficjalatu i wikariatu krakowskiego do połowy XVI wieku, Kraków 2010.

Koczerska M., Kancelarie konsystorskie, w: Dyplomatyka staropolska, Warszawa 2015.

Kowalski M.D., Dlaczego warto było zostać kolektorem? Kariery papieskich kolektorów generalnych w Polsce w XV wieku, Roczniki Historyczne 80, 2014.

Kozak A., Miejsca działalności konsystorza generalnego w Poznaniu i jego pisarzy w pierwszej ćwierci XV w., w: Loca scribendi. Miejsca i środowiska tworzące kulturę pisma w dawnej Rzeczypospolitej XV-XVIII stulecia, Warszawa 2017.

Kozak A., Łukaszewski J., Późnośredniowieczne dokumenty papierowe odnalezione w katedrze gnieźnieńskiej, Studia Gnesnensia 29, 2015.

Litewski W., Der römisch-kanonische Zivilprozeß nach den älteren ordines iudiciarii, Kraków 1999.

Longley K.M., Ecclesiastical Cause Papers at York: Dean and Chapter's Court 1350-1843, York 1980.

Łukaszewski J., Fragmenty dwóch nieznanych druków z oficyny Jana Hallera (z 1506 i 1509 roku), Biblioteka 20 (29), 2016.

Nowacki J., Dzieje archidiecezji poznańskiej, t. II, Poznań 1964.

Pest C., Przeszłość i współczesność Archiwum Archidiecezjalnego w Gnieźnie, Poznańskie Studia Teologiczne 11, 2001.

Rolny W., Przedmowa, w: Acta officii consistorialis Leopoliensis antiquissima, cz. I, wyd. W. Rolny, Lwów 1927.

Rył J., Biblioteka Katedralna w Gnieźnie, Lublin 1978.

Rył J., Biblioteka Katedralna w Gnieźnie w latach 1650-1975, Lublin 1985.

Schwab Ch., Das Augsburger Offizialatsregister (1348-1352). Ein Dokument geistlicher Diözesangerichtsbarkeit. Edition und Untersuchung, Köln-Weimar-Wien 2001.

Skierska I., Konsystorz gnieźnieński w XV wieku, w: 1000 lat Archidiecezji Gnieźnieńskiej, Gniezno 2000.

Skierska I., Sabbatha sanctifices. Dzień święty w średniowiecznej Polsce, Warszawa 2008.

Skierska I., Sądownictwo oficjałów okręgowych (foralnych) w późnośredniowiecznej Polsce, w: Sacri canones servandi sunt. Ius canonicum et status ecclesiae saeculis XIII-XV, Praha 2008.

Skierska I., Źródła do badania praktyk religijnych w średniowiecznej Polsce: akta sądów kościelnych i kapituł, Archiwa, Biblioteki i Muzea Kościelne 87, 2007.

Smith D.M., Ecclesiastical Cause Papers at York: The Court of York 1301-1399, York 1988.

Subera I., Powstanie i rozwój właściwości sądów kościelnych w Polsce, Prawo Kanoniczne 11, 1968, nr 3-4.

The Records of the Medieval Ecclesiastical Courts. Reports of the Working Group on Church Court Records, t. I: The Continent, t. II: England, red. Ch. Donahue Jr., Berlin 1989-1994.

Vetulani A., Prawne stanowisko oficjałów biskupich w Polsce w XV stuleciu, w: Studia historyczne ku czci Stanisława Kutrzeby, t. 1, Kraków 1938.

Wilk-Woś Z., Późnośredniowieczna kancelaria arcybiskupów gnieźnieńskich (1437-1493), Łódź 2013.

Zathey J., Katalog rękopisów średniowiecznych Biblioteki Kórnickiej, Wrocław 1963. 


\title{
The consistorial documentation from the 15 th and early 16 th centuries discovered in Gniezno Cathedral
}

\begin{abstract}
Summary
In August and September 2015 six boxes of unknown late medieval paper documents were found in a room over the northern nave of Gniezno Cathedral, which served as a storage of damaged acts of the Archdiocesan Archive. The collection had already been discovered in 1961 during the works on regothisation of the cathedral, but no cataloguing or conservatory works were started, and the information about the discovery did not reach the scholarly community, so the finding had been forgotten. The provisional study undertaken now made it possible to establish that the collections contains about five hundred documents preserved in full or major parts and over two thousand small fragments. The date mostly from the second half of the $15^{\text {th }}$ and early $16^{\text {th }}$ centuries. They testify to the activities of the archbishop's consistory in Gniezno. The collection primarily consists of officials' mandates, legal proclamations of the sides in court cases (libelli and positiones of various types), and protocols of witnesses' testimonies (six examples of such documents are appended to the paper). In the collections of Polish archives only occasionally can one find similar documentation (mandates of officials from Włocławek or process writings sewed into the books of inscriptions in Gniezno and Poznań), examples of which are now known mostly from formulary books, textbooks of process Canon law (ordines iudiciarii) and inserts in other documents. The newly rediscovered documents may be compared to the so-called cause papers, known from the archdioceses of Canterbury and York.
\end{abstract}

Translated of Rafat T. Prinke 